\title{
Confederation debt management since 1970
}

\author{
Basil Guggenheim ${ }^{1}$, Mario Meichle ${ }^{2}$ and Thomas Nellen ${ }^{3^{*}}$ (D)
}

\begin{abstract}
This paper analyzes the Confederation's debt management. The Confederation actively manages roll over and interest rate risk by increasing bond maturity with increasing marketable debt-to-GDP levels. It further engages in active but asymmetric, one-sided interest rate positioning; i.e., it uses mostly bonds to affect debt maturity and does so only when the interest rate environment is favorable to lock-in interest rates by issuing longer-term bonds. Debt management is mainly driven by marketable debt rather than total debt. Issuing behavior became more regular and demand-oriented during the early 1990s when marketable and total debt increased in tandem.
\end{abstract}

Keywords: Government debt, Government debt management, Government debt maturity

JEL classification: $\mathrm{E} 63, \mathrm{H} 63$

\section{Introduction}

This paper empirically analyzes the Confederation's debt management based on new data vintages on marketable debt emissions and total outstanding debt from 1970 on. Debt management is about deciding which debt instruments the government uses to finance itself over time. In so doing, treasuries face the trade-off between the debt servicing cost against potential costs of roll over and interest rate risk. For instance, predominantly issuing short-term debt to reduce servicing costs can increase the level and volatility of tax rates when short-term rates rise. This is associated with deadweight costs of increasing taxation. These risks may partly be hedged issuing longer term maturities next to short-term debt.

Switzerland is an interesting case study as the Confederation-despite increasing debt levels in the 1990s - has not accumulated debt levels exceeding 60\% of GDP during the analyzed sample period and is considered as one of the most stable political countries with a high degree of central bank independence. Thus, the Confederation's prime trade-off is indeed between

\footnotetext{
* Correspondence: thomas.nellen@snb.ch

The views expressed in the paper are those of the authors and do not necessarily reflect those of the Federal Department of Finance, PostFinance $A G$ and the Swiss National Bank.

${ }^{3}$ Swiss National Bank, Financial Stability - Oversight, Börsenstrasse 15, 8022

Zürich, Switzerland

Full list of author information is available at the end of the article
}

the cost of debt servicing and the costs of roll over and interest rate risk rather than costs related to the Confederation's default risk. Also, the Confederation has been facing constantly decreasing debt levels since 2006 in response to the introduction of the debt break in 2003, a rather unique feature among developed economies worldwide. Given the sample, we are further able to shed light on the Confederation's response to the global financial crisis (GCF) and the subsequent low and ultra-low interest rate levels. Additionally, the Confederation's total debt consists to a substantial and vastly changing degree of non-marketable debt. Going beyond existing literature, we explicitly account for non-marketable debt and how non-marketable debt affects debt management.

Similar to the USA, we find that the Swiss Federal Treasury (henceforth the Treasury) increases marketable debt maturity with an increasing marketable debt-to-GDP ratio. Hence, the Treasury hedges actively against roll over and interest rate risk. This is done despite comparatively much lower levels of debt. While we cannot rule out that the positive correlation between increasing maturity and marketable debt-to-GDP levels may be driven to some degree by technical factors, ${ }^{1}$ the qualitative and quantitative

\footnotetext{
${ }^{1}$ Constant issuing behavior in tandem with an increasing level of marketable debt to GDP automatically results in an increasing maturity when the issued maturity is higher than the outstanding maturity.
} 
evidence provided over a period of 46 years with constant, increasing and decreasing debt-to-GDP levels suggests that the Treasury actively steers roll over and interest rate risk.

However, in contrast to the USA, the Confederation does not do so by targeting a specific maturity target. The evidence rather indicates that the Treasury engages in active asymmetric and one-sided interest rate positioning. Interest rate positioning is asymmetric, as the Treasury mostly relies on bonds to influence debt maturity. In other words, the share of short-term debt seems to be less actively used to affect marketable debt maturity. This points to a cash management-driven use of short-term debt. Furthermore, qualitative evidence from the state financial statement (SFS) indicates that the Treasury engages in one-sided interest rate positioning. In other words, the Treasury seems to increase the maturity of bonds only in response to a favorable interest rate environment, but appears not to actively reduce debt maturity when the interest rate environment is unfavorable. This can be interpreted as long-term interest-rate fixing in order to lock-in a favorable interest rate environment to reduce and stabilize the future interest burden.

While asymmetric and one-sided interest rate positioning is most visible during the last part of the sample, qualitative and descriptive evidence suggest that this policy has been followed before and was not a mere reaction to the low interest rate environment after the GFC. Most strikingly, despite decreasing debt-toGDP levels, the Treasury has increased the average maturity of bond before the GFC.

To engage in this study, we harvested a new data set on all emissions of marketable Confederation debt from 1970 onwards. These data include zero-coupon instruments (bills and notes) and new emissions, replenishments, and sales of own tranches of bonds. Additionally, we present data on yearly debt composition extracted from the state financial statement (SFS; Staatsrechnung), i.e., the Confederation's finance and balance sheet report. The latter data are annual and serve to disentangle total debt into marketable and nonmarketable debt. Increasing public sector liabilities of the Confederation and changes in debt accounting allowed to fund an increase of total debt in the late 1970s and early 1980s. ${ }^{2}$ This led to a growing nonmarketable debt share with peak shares in total debt of over $65 \%$. From the 1990 s onwards, the increasing marketable debt share was driven by the strong increase in the total debt level of the Confederation and a shift toward marketable funding sources.

\footnotetext{
${ }^{2}$ Non-marketable debt from private sector sources has never reached a sizeable share of total debt, but was regularly used to fund increasing debt levels during the 1990s.
}

Thus when analyzing the Confederation's debt management, it is important to account for non-marketable debt. The evidence suggests that non-marketable debt plays a negligible role in marketable debt management. In particular, the share of non-marketable debt-to-GDP does not affect the issuing behavior neither in terms of outstanding bond maturity nor the share of short-term debt. This is consistent with the fact that nonmarketable debt primarily consists of public sector deposits. These deposits are perceived to behave similar to bank deposits in that they represent an inexpensive and stable source of funding being subject to slow-moving political processes. Also, interest rates on these deposits react similar to bank deposits, slowly rising if facing interest rate increases and quickly falling if facing interest rate increases. Thus, non-marketable debt is prone to considerably lower roll over and interest rate risk than marketable debt. Consequently, we find that the Treasury's debt management primarily reflects the extent of marketable debt and the prevailing interest rate environment in its issuing of marketable debt.

The Treasury's debt-issuing behavior became more regular and demand-oriented with increasing marketable and total debt levels in the 1990s. Before this, the Treasury's issuing behavior was more infrequent and largely driven by changing funding requirements depending on budget outcomes or changes in non-marketable funding sources. Exceptions were the more regular emission activities for notes and bills. While notes only slowly ceased after the introduction of bills in 1979, their issuance was rather insignificant and-related to discountwindow needs-became demand-driven after 1979.

Several changes in the early 1990s marked the move to regular debt management. The possibility of replenishing outstanding bonds by means of a regular auction process was introduced in 1991. In 1993, the Treasury introduced so-called own tranches, i.e., the Treasury sells own tranches directly to one or several investors. These changes coincided with the Treasury serving more and more maturities when issuing new bonds or replenishing existing bonds. Furthermore, the Treasury introduced an emission calendar in 1992, informing investors about auction dates and expected yearly gross and net volumes. While the introduction of replenishments contributed to a more frequent and regular issuing pattern, both the use of direct placements of own tranches and the use of replenishments further indicate the Treasury's demand orientation.

\subsection{Literature}

We fill a void in the literature by looking at the Confederation's debt management from a broad perspective. ${ }^{3}$ The notable other paper on Confederation 
debt management is Ranaldo and Rossi (2016). They analyze a specific aspect of Swiss debt management, sketching out the history of the Confederation's debt auctions that started in 1980. They describe how the institutional set-up evolved over time (i.e., bidding requirements, class of bidders, communication, etc.), and they elaborate on why the Confederation chose the uniform-price auction as its preferred type of emission procedure. ${ }^{4}$

Conceptually, our approach is inspired by Greenwood, Hanson, and Stein (2015) who understand optimal debt maturity as a simple tradeoff. On the one hand, due to its liquidity and its safety, government debt is valued above commercial debt. Thus, if the government tilts its issuance to shorter maturities, it faces lower expected financing costs. On the other hand, given that future market conditions are unpredictable, a strategy of short-term financing exposes the government to roll over and interest rate risk. As a number of other papers have noted, these risks may lead to real costs insofar as they could increase the tax level and its volatility. ${ }^{5}$

\footnotetext{
${ }^{3}$ The literature on Swiss government debt is focused almost exclusively on the Confederation's debt brake and its cantonal pendants. Most recent papers are found in the 2013 special issue of the Swiss Journal of Economics and Statistics devoted to the tenth anniversary of the Confederation's debt brake. Papers in this special issue and in Geier (2011a, 2011b) provide an extensive overview of the existing literature and an in-depth analysis of the debt brake. Different authors investigate fiscal mechanisms in Swiss cantons. Marti Locher (2015) shows that due to the federal structure and high autonomy of the Swiss cantons, cantonal fiscal rules differ broadly in their purpose, institutional framework, design and time of introduction. Her empirical analysis, focusing on three fiscal rules implemented in the 1990s, shows that the efficacy of these fiscal rules is highly dependent on the institutional framework and the design of the rule. Earlier literature such as Kirchgässner (2013) concludes that with well-designed institutions, federal states might be able to better follow a sustainable fiscal policy. Beljean and Geier (2013) describe how a binding ceiling for expenditure has changed the budget process to enable it to achieve fiscal objectives more successfully. They further argue that the rule is best set up as a simple and transparent mechanism. More relevant in our context, the stabilization of nominal debt around 2005 is ascribed to the debt brake. Earlier relevant literature includes Debrun, Epstein, and Symansky (2008), Feld and Kirchgässner (2006), Bodmer (2006), Colombier (2004), Himmel and Geier (2004), Bruchez (2003), Geier and Bodmer (2003), Danninger (2002) and Colombier and Frick (2001).

${ }^{4}$ This relative dearth of Swiss literature mirrors the general scarcity of debt-management literature. Favero, Missale, and Piga (1999) and Missale (1999) provide the most recent comprehensive studies on debt management. Later on, Garbade (2004), Garbade and Ingber (2005), Garbade (2007), Garbade and Rutherford (2007), and Garbade (2008) analyze particular aspects of U.S. debt management, while de Haan and Wolswijk (2005) provide an EMU-wide perspective motivated by the introduction of the euro in 1999. From a practitioner's perspective, papers of supranational institutions such as the OECD, IMF or World Bank provide insights into a broad range of issues related to public debt management. Most of these studies are cited in the recently revised Guidelines for Public Debt Management (IMF, 2014).
}

Methodologically closest to our paper is Garbade and Rutherford (2007), who analyze data on US federal debt, suggesting that the US Treasury actively manages its issuance and repurchases to achieve a target maturity of outstanding debt. Also, similar to Greenwood et al. (2015), we estimate equations that can be interpreted in terms of a partial adjustment model of the maturity of government debt. They find the average maturity of newly issued debt to increase with the debt-to-GDP ratio. Thus the US government gradually adjusts the maturity of its new issuance toward longer-term debt if the debt-to-GDP level increases.

Our data harvest newly allows to address related research fields with Swiss data. Renewed interest in a particular aspect of debt management, namely the maturity structure of government debt, was triggered by the large-scale asset purchases in the USA. Taking earlier scholars such as Culbertson (1957), and Modigliani and Sutch (1966) as their starting point, there is a growing literature that documents significant deviations from the predictions made by standard asset-pricing models with regard to the term structure of interest rates. To mention two recent papers, Krishnamurthy and VissingJorgensen (2012) find that the liquidity and safety of government debt drive down their yield relative to other assets, while Greenwood and Vayanos (2014) analyze how government debt maturity and the debt-to-GDP ratio influence the term structure of interest rates.

The before mentioned branch of literature has more generally renewed interest in the optimal maturity structure of government debt going back to the work of Barro (1979) and Lucas and Stokey (1983) on optimal taxation and debt management over the business cycle. Buera and Nicolini (2004) and Angeletos (2002) represent benchmark specifications in an incomplete market setting with debt of different maturities. These models fail to observe typical treasury behavior that more recent literature tries to replicate by means of restricting the government from going short in any maturity (Lustig, Sleet, and Yeltekin (2008), restricting the government's ability to commit (Debortoli et al., 2017), tying model closer to observed asset prices (Bhandari et al., 2017), considering the price impact of each issuance of an impatient government (Bigio, Nuño, \& Passadore, 2018) and restricting the government ability to rebalance its portfolio (Faraglia et al., 2018).

Additionally, the GFC led to a rethinking of the relationship between monetary policy and debt management. Greenwood et al. (2015) propose debt management as a macroprudential instrument. Insofar as

\footnotetext{
${ }^{5}$ See, e.g. Barro (1979), Lucas and Stokey (1983), Bohn (1990), Angeletos (2002), Aiyagari, Marcet, Sargent, and Seppälä (2002), and Nosbusch (2008).
} 
there are negative externalities associated with private money creation, the government should tilt its issuance more toward short maturities. Because the government has a comparative advantage relative to the private sector in bearing refinancing risk, the government may crowd out the private sector's excessive use of short-term debt. ${ }^{6}$

Greenwood, Hanson, Rudolph, and Summers (2014) also analyze how monetary policy at the zero lower bound interacted with government debt management during the financial crisis. While the Federal Reserve System (FRS) tried to reduce long-term debt, the US Treasury tilted its debt management toward long-term debt issuance, partially off-setting the effects targeted by the FRS's quantitative easing programs. They suggest revising institutional arrangements to promote greater cooperation between the US Treasury and the FRS in setting debt management policy, particularly during times when monetary policy is constrained (for instance by the effective lower bound). ${ }^{7}$

Section 2 presents data on emissions and total outstanding debt. Section 3 is devoted to debt management and issuance behavior. Section 4 discusses the maturity composition of marketable debt and factors that influence it. Section 5 provides an econometric analysis of the issuing behavior of the Treasury. Section 6 concludes.

\section{Data and debt composition}

In this section, we present the data harvest and the evolution of the Confederation's debt composition.

We harvested two sets of data to present an overall picture of the Confederation's debt developments since 1970. First, data on Confederation emissions of marketable debt were harvested. Secondly, yearly data on the Confederation's total outstanding debt and liabilities were collected.

Data on emissions stem from diverse sources, ranging from an internal database of the Treasury ${ }^{8}$, publications of the SNB, archive material, and IT database material of the SNB, to data archived by SIX Telekurs. The data cover the period from 1848 onwards. Appendix 1 provides an indepth description of the diverse sources and explains how we verified the data. With two caveats, emission data are judged to be complete from 1970 onwards: emission data on notes might be missing for the years 1980 to 1982; furthermore, until 2009, the Treasury would sometimes buy

\footnotetext{
${ }^{6}$ See also Stein (2012) and Krishnamurthy and Vissing-Jorgensen (2015) for similar arguments.

${ }^{7}$ The suspension of bond issuance by the Danish government in early 2015 to limit FX inflow and ease upward pressure on the Danish krone is an example of such an institutional cooperation.

${ }^{8}$ The Federal Treasury, a unit within the Federal Finance Administration, which is part of the Federal Finance Department, conducts debt management for the Confederation.
}

back bonds shortly before the due date. Bearing these two points in mind, it otherwise holds true that the data are correct at year-end, but may exhibit negligible intra-yearly distortions until 2009.

Yearly data on the Confederation's total debt were taken from the state financial statements (State Financial Statement, n.d.), published by the Federal Finance Administration (FFA), Geier (2011a), and the Schuldenbericht (2006) - a report by the Federal Council on the development of public debt since 1950. These data sources provide historical data on the level of total debt. Additionally, the SFS allows us to decompose the Confederation's debt into its different funding sources (see Appendix 1 for a more detailed description). GDP data are taken from the Swiss Federal Statistical Office and the State Secretariat for Economic Affairs. ${ }^{9}$ Additionally, the 3-month Libor/Euromarket interest rate and the 10year yield on government bonds is publicly available on the SNB's website. The data start in 1974.

The Confederation's total debt can be categorized into marketable and non-marketable debt. We define marketable debt as securities issued either in the form of Treasury bills (Geldmarktbuchforderungen; henceforth bills), Treasury notes (Schatzanweisungen; notes), or Confederation bonds (Eidgenossen; bonds). Bond emission data include direct sales of own tranches to investors and replenishments. While bonds have yearly fixed coupon payments, Treasury notes and Treasury bills are issued as zero-coupon instruments. The emission data harvested include value, maturity (settlement and redemption date), yields, coupon payment, and emission price. Table 1 shows descriptive statistics. ${ }^{10}$

Emission data consist of 3098 issuances; approximately one-third are emissions of bonds. In total, debt with a nominal value of CHF 1.22 trillion was issued between 1970 and 2016; CHF 0.99 trillion alone is due to the more

\footnotetext{
${ }^{9}$ Note that GDP data were revised in autumn 2014 due to the transition to a new accounting system (European Commission, 2010). This revision had a substantial impact on the level and the different accounting aggregates, though it left growth rates almost unaffected. For the regression analysis, growth rates are of particular importance. Also, the new data according to ESA 2010 starts in 1980, while our analysis goes back to 1970. For these reasons, we keep to pre-revision data according to ESA 95.

${ }^{10}$ In reading descriptive statistics, it is important to remember that notes were largely replaced by bills from 1979 and particularly from 1986 onwards (SFS, 1986). Afterwards, notes issuance remained low and ceased altogether in 2005. Also, notes were often used to satisfy particular demands. For instance, longer maturities were issued due to specific demand from Liechtenstein banks in need of securities eligible for the SNB's Lombard facility (SFS, 1986, and Nellen, 2015). Three convertible bonds-issued between 2005 and 2007 to reduce the government's equity stake in the former public telecommunications provider Swisscom - are excluded from the database since they are not comparable with conventional bond issuance.
} 
Table 1 Descriptive statistics of Swiss Confederation marketable debt issuance data from 1970 to 2016

\begin{tabular}{|c|c|c|c|c|}
\hline & All & Bonds & Bills & Notes \\
\hline Number of issues & 3098 & 1085 & 1373 & 640 \\
\hline \multicolumn{5}{|l|}{ CHF (millions) } \\
\hline Total & $1,218,711$ & 196,006 & 992,494 & 30,211 \\
\hline Mean & 393 & 181 & 723 & 47 \\
\hline SD & 396 & 233 & 329 & 66 \\
\hline Min & 1 & 1 & 75 & 1 \\
\hline Max & 2512 & 1553 & 2512 & 385 \\
\hline \multicolumn{5}{|l|}{ Term to maturity } \\
\hline Mean & 5.4 & 14.5 & 0.3 & 1.0 \\
\hline SD & 8.7 & 9.4 & 0.2 & 1.1 \\
\hline Min & 0.1 & 2.0 & 0.1 & 0.1 \\
\hline $\operatorname{Max}$ & 50.0 & 50.0 & 1.0 & 8.0 \\
\hline \multicolumn{5}{|l|}{ Yield (\%) } \\
\hline Mean & $2.756 \%$ & $3.191 \%$ & $1.809 \%$ & $4.049 \%$ \\
\hline SD & $2.075 \%$ & $1.325 \%$ & $2.203 \%$ & $1.880 \%$ \\
\hline Min & $-1.521 \%$ & $-0.545 \%$ & $-1.521 \%$ & $0.110 \%$ \\
\hline Max & $9.102 \%$ & $7.815 \%$ & $9.102 \%$ & $8.875 \%$ \\
\hline
\end{tabular}

frequent bill emissions owing to the short-term nature of the instrument. The average issue size was CHF 181 million for bonds, CHF 723 million for bills, and a relatively small amount of CHF 47 million for notes. As bond emissions include piecewise replenishments of already outstanding bonds from 1991 onwards as well as smallersized tap sales of own tranches of bonds from 1993 onwards, the variability of the bond issue volume is higher than for other debt instruments. The maximum issue amount was CHF 1.6 billion for bonds, CHF 385 million for notes, and CHF 2.5 billion for bills. On average, the term to maturity at issuance for bonds was 14.5 years. ${ }^{11}$ Short-term debt instruments such as bills (notes) show a much shorter average term to maturity of slightly more than 4 months (1 year). Notes were mostly issued to banks, partly due to specific demand, and thus cover a broader range of maturities between 1 month and 8 years. On average, debt issued earned a yield of $2.76 \%$ (with a broad range of yields including negative yields). ${ }^{12}$

We further collected yearly data on total debt from the SFS (1973-2014), Geier (2011a), and the Schuldenbericht (2006). We use the series by Geier (2011a) as an

\footnotetext{
${ }^{11}$ Contrary to the following sections, the average term to maturity in Table 1 is not volume-weighted.

${ }^{12}$ Conventional bond yields reached their low with the sale of an own tranche of the 2022 bond in 2015 at $-0.545 \%$. Bills have been issued with negative yields since summer 2011. Historical lows of around $1.5 \%$ were reached at the end of 2015.
}

accepted approximation of the long-term dynamics of the Confederation's debt. ${ }^{13}$ More importantly, besides identifying the total debt level of the Confederation, balance-sheet data allow us to decompose total debt into the different funding sources, such as marketable debt and non-marketable debt.

We refer to all debt components that are not issued as securities as non-marketable debt. The most important components of non-marketable debt across time were deposits of related institutions (e.g., railway, post, social insurances, etc.), deposits of employees at the Confederation's own savings bank (the employees' credit union), liabilities to the Confederation's pension fund, and accounting-related liabilities such as current accounts of provinces (cantons) or other short-term liabilities. ${ }^{14}$ In addition, there are other rarely used forms of market funding across the sample period, such as money market credits, fixed deposits of retail clients, or other forms of bank loans.

Figure 1 provides a decomposition of total debt into marketable and non-marketable debt. Total debt increases until the mid-1980s, then remains constant until 1990. The increase in debt from 1980 to 1981 stems mainly from a change in the debt definition, in particular the inclusion of liabilities against the Confederation's pension fund. Total debt increases greatly during the 1990s, reaching a record high of almost CHF 130 billion in 2005, when it started to decrease again. The main reasons for the debt increase were substantial deteriorations in the ordinary fiscal balance, restructuring and the financial recovering of government-owned companies, loans to unemployment insurance, and outfinancing pension funds (Beljean \& Geier, 2013; Schuldenbericht, 2006). In 2003, a debt brake mechanism came into force that led to a stabilization of the Confederation's total debt until 2005. The ongoing budget surpluses have been primarily responsible for supporting the reduction of total debt since 2006.

The composition of total debt, as marketable debt and non-marketable debt, changes with total debt levels. Whereas marketable debt increased until 1976, it

\footnotetext{
${ }^{13}$ Data on total debt shows several structural breaks due to different debt definitions and accounting practices. Thus changes in the level of debt, in particular at the end of the 1970s and 1980s, must be interpreted carefully. In addition, debt reported in the state financial statements may differ slightly from debt reported according to Maastricht or IMF criteria and their definitions. Geier (2011a) provides an approximation of the debt dynamics.

${ }^{14}$ Throughout the 1990s and until 2005, non-marketable debt components were strongly affected by outsourcing and the (partial) privatization processes of public corporations (e.g. postal and telecommunication services), the financing of related pension funds and the discontinuation of central treasury services by the Confederation for these institutions.
} 


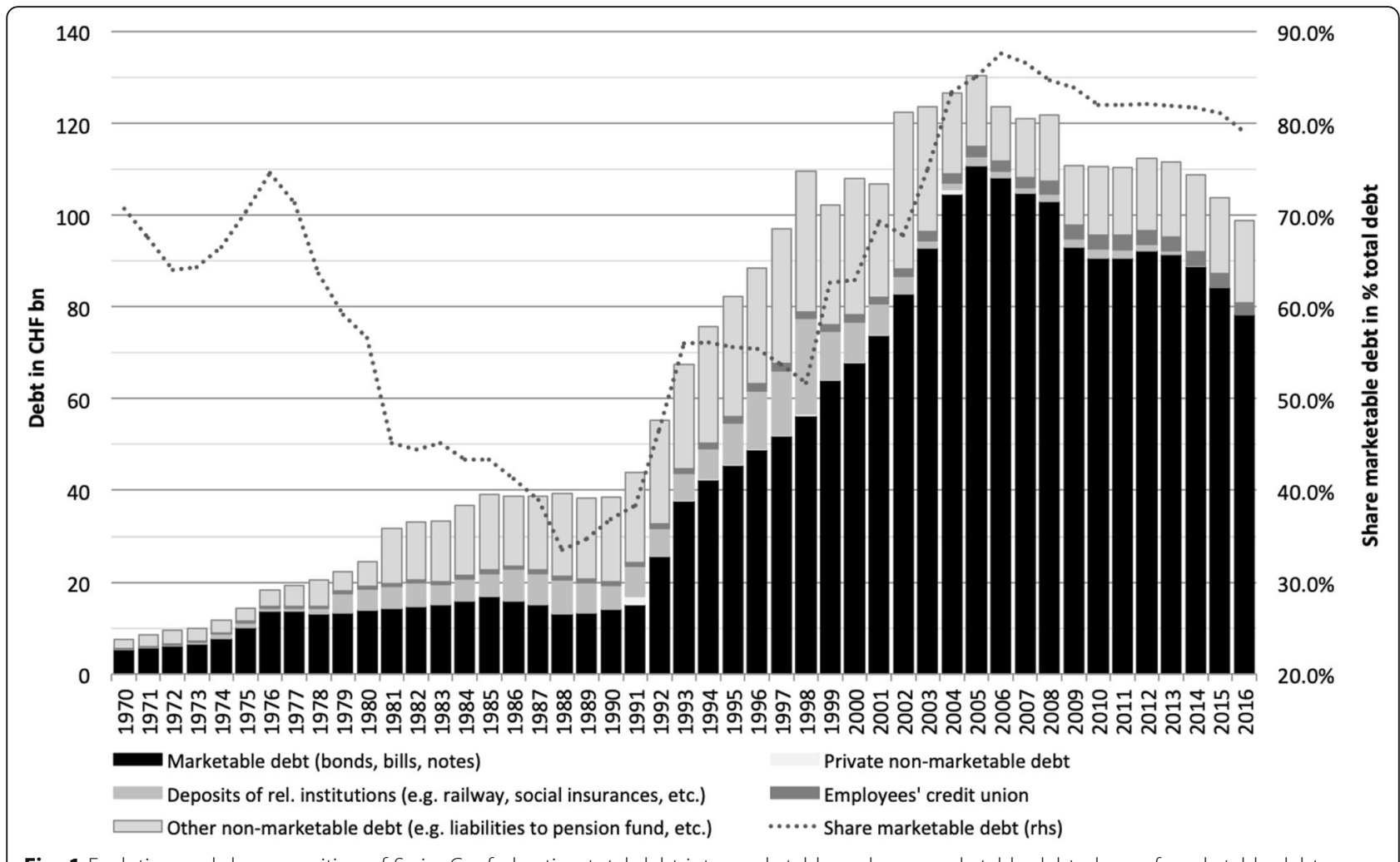

Fig. 1 Evolution and decomposition of Swiss Confederation total debt into marketable and non-marketable debt, share of marketable debt

remained more or less constant until 1991. Increasing total debt levels until 1991 were mainly due to increasing liabilities against the Confederation's pension fund and their inclusion in the debt aggregate. In addition, increasing deposits of related institutions fueled the Confederation's liabilities. From the early 1990s until 2005, sizable deficits and other financial burdens outlined above forced the Confederation to issue more and more marketable debt as public non-marketable funding sources remained constant (and slightly decreased in the late 1990s). In general, the government rarely had recourse to other private non-marketable debt. With the exception of the early 1990s, when all sources had to be used to obtain sufficient funding, these forms of debt tended to play a role within cash management or retail funding. However, their overall importance remained negligible in terms of total debt.

The marketable debt share decreased from the mid1970s until the beginning of the 1980s. This was mainly related to increasing funding through current account and term deposits of government-related institutions. The marketable debt share further decreased during the 1980s due to the extension of the debt definition and increasing internal liabilities against the pension fund and other funding sources. From 1990 onwards, increasing total debt levels had to be financed primarily by marketable debt by issuing marketable debt in the form of bills, notes, and bonds. This increased the share of marketable debt over time, peaking at $92 \%$ in 2006. After 2006, slightly decreasing levels of debt together with stable public sector liabilities and funding resulted in a slightly decreasing level of marketable debt, reaching around $80-85 \%$ during the last 5 years. Although the share remained almost constant during these years, there was again a change in the composition of non-marketable debt. Liabilities against the Confederation's pension fund were reduced from 2000 onwards and vanished after 2007. ${ }^{15}$ This reduction in non-marketable debt was, however, compensated through an increasing share of other public sector non-marketable debt, such as current accounts of cantons or other shortterm liabilities (e.g., withholding tax claims).

Figure 2 provides a decomposition of marketable debt. Unsurprisingly, the composition of marketable debt is characterized mainly by bonds. Notes were issued to a non-negligible extent, mainly during the 1970s. The 1980s saw a decreasing share of notes. This was related to the introduction of bills in 1979, with the aim of establishing a CHF money market and of increasing the range of funding instruments. ${ }^{16}$ The last note was finally issued in 2005. Bills gained an increasing share of

${ }^{15}$ This is related to the foundation of the autonomously organized Federal pension fund PUBLICA and outsourcing of its funds from the federal balance sheet. See SFS (2008). 


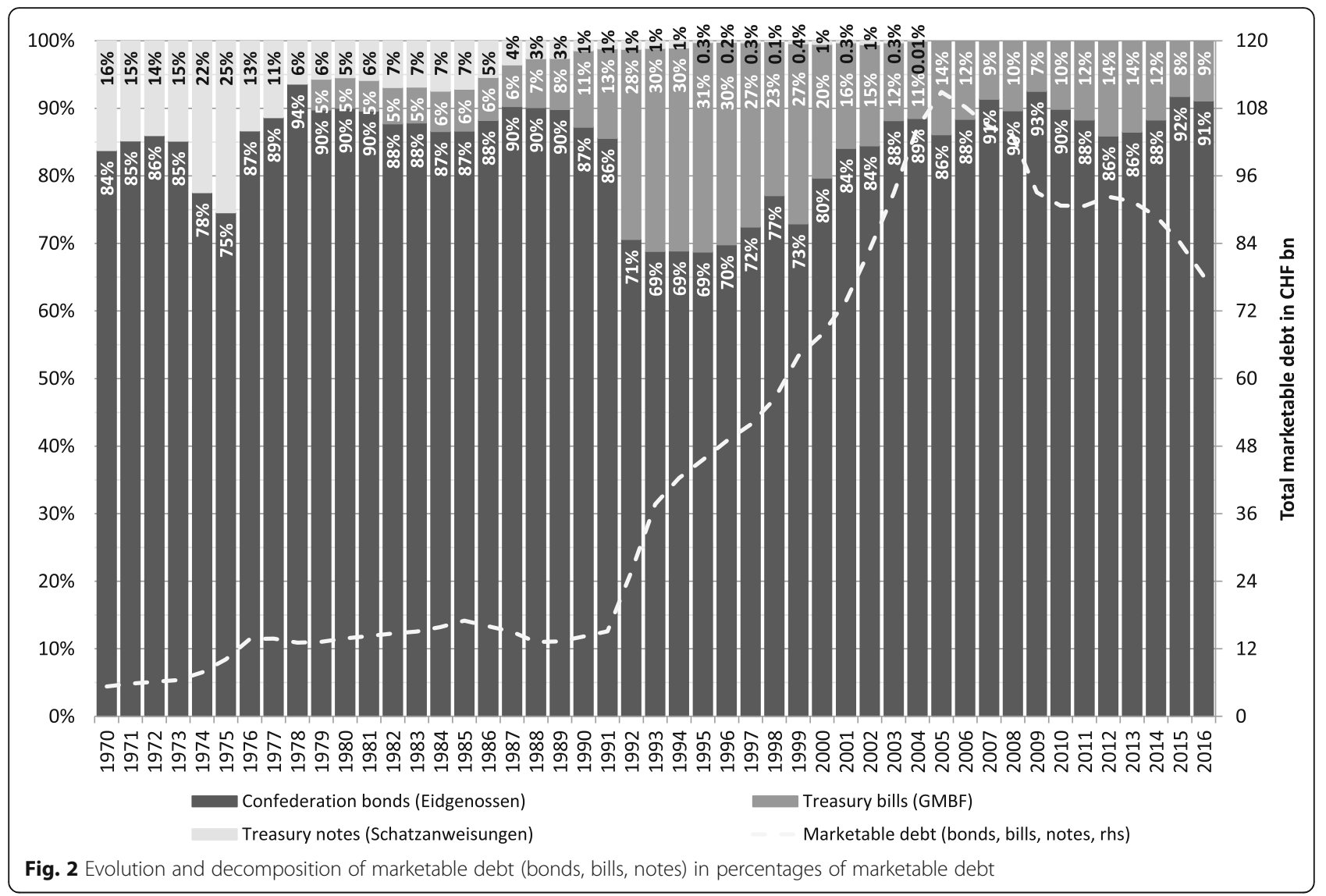

marketable debt during the early 1990s, when the Treasury initially financed substantial deficits and other financial burdens by issuing short-term debt. This was further driven by cost concerns due to the high level of the interest rate at the time. ${ }^{17}$ In 1995 , the share of bills started to decline again. Since 1995, the Treasury has steadily increased its interest commitment in response to declining interest rates, on average issuing relatively more bonds. ${ }^{18}$ Since 2003, the share of bills has remained constant, fluctuating at around $10-15 \%$. The decline in marketable debt since 2006 has been managed by somewhat symmetric reductions in both outstanding bonds and bills. Before 2012, the lowered funding need led to an increase in the share of bills that was connected to the decline in bond issuances. The more recent decline in the share of bills indicates that ultra-low interest rates and the reduced funding need have prompted a growing reliance on bond issuances.

An increasing share of bills is often related to higher amounts of liquidity needed at the end of the year and the beginning of the next year, to prepare bond

\footnotetext{
${ }^{16}$ See SFS (1979).

${ }^{17}$ See SFS (1990-1992).

${ }^{18}$ See SFS (1995-2005).
}

redemptions early in that year. This seems to have been the case in 2008 and in the years from 2011 to $2013 .{ }^{19}$ In 2015 , the share of bills dropped further, as the negative interest rate environment caused withholding tax and federal direct tax to be delivered earlier by the cantons. In order to lower the level of liquidity, the Treasury reduced market funding and, in particular, considerably reduced bills issuance. ${ }^{20}$

\section{Marketable debt issuance}

In this section we describe the evolution of marketable debt issuance. The Treasury's emission practices have become more predictable and regular from the early 1990s onwards. We first focus on net issuance and then take a closer look at the individual instruments (bonds, bills and notes).

Figure 3 shows yearly debt redemptions and net issuances, i.e., debt issued minus debt coming due. The grey-shaded areas in Fig. 3 mark years of long-term interest rate positioning. These years take into account only the self-declarations by the Confederation in the

\footnotetext{
${ }^{19}$ See e.g. SFS (2012).

${ }^{20}$ See Federal Finance Administration (2016).
} 


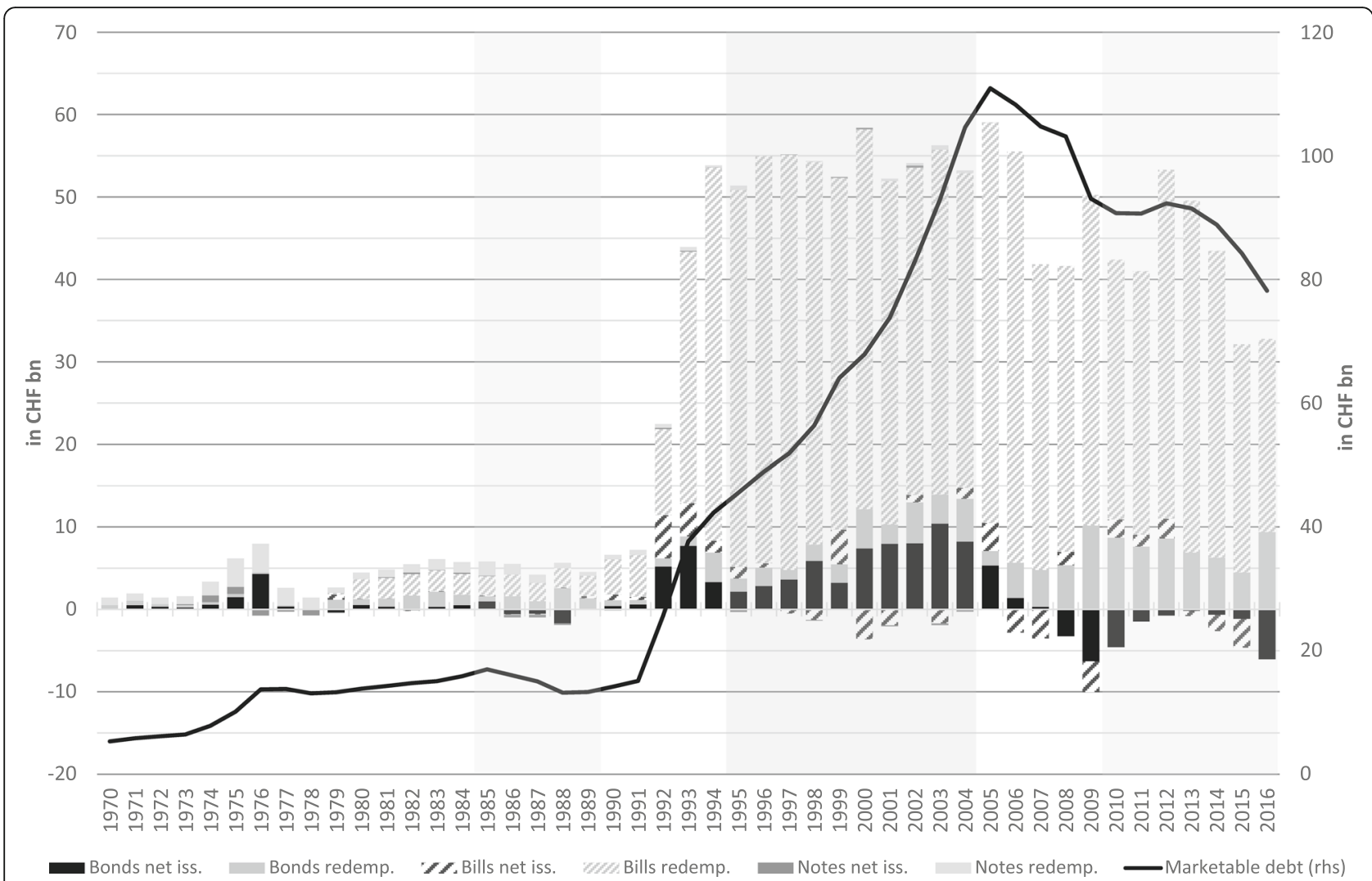

Fig. 3 Net issuance and redemptions of decomposed marketable debt (i.e., bonds, bills, and notes) and evolution of marketable debt

SFS. During these periods, the Treasury claimed to have engaged in longer-term maturities to profit from a low interest rate level.

In the mid-1970s, marketable debt increased slightly and was primarily funded with an increasing net issuance of bonds, ${ }^{21}$ whereas the issuance of notes was mainly determined by redemptions and market demand. Changes in total debt in the late 1970s and 1980s were primarily covered by increasing internal non-marketable debt, i.e., by increasing internal funding, term deposits, and changes in the debt definition. Thus, constant marketable debt implied that the issuance of all debt instruments was determined by debt coming due and that the net issuance was close to zero. This was particularly the case for the newly issued bills and notes. These instruments' near constant share in marketable debt during this period (see Fig. 2) is reflected in their zero net issuance and near-constant redemption values in Fig. 3. In the second half of the 1980s, the Confederation faced lower funding needs and a lower or negative net issuance of bonds. However, the Treasury considered the interest rate environment as favorable. Consequently, the Treasury increased its interest rate commitment to reduce the long-term interest burden. ${ }^{22}$ Facing a lower net issuance of bonds, the Treasury therefore called in or converted callable higher-yielding bonds into loweryielding, newly issued bonds.

Since the majority of bills issued has a term to maturity below one year, their total yearly issued volume is naturally greater than the issued volume of longer-term debt instruments. As the Treasury started a general expansion of the bill program to build up a Swiss franc money market in around 1990 (which also increased the relative importance of this funding instrument as displayed in Fig. 2), this is when bill redemption started to grow. On top of this, and despite the inverse termstructure at the time, the Treasury regarded the prevailing longer-term interest rate level as high. Thus the Treasury increased its short-term debt issuance beyond the build-up intended to promote a Swiss franc money market. ${ }^{23}$ After 1990, the issuance of notes only played a negligible role (see also below). 
With the increasing funding needs in the early 1990s, the issuance of both bills and bonds substantially exceeded debt coming due, leading to an increase in net issuance of both instruments. Increasing funding needs persisted in the late 1990s due to continued deficits and in the first half of the 2000s due to the liberalization of former public entities. ${ }^{24}$ Between 1995 and 2005, in the light of the downward trend in interest rates, the Treasury attempted to take advantage of lower funding costs and covered its funding needs increasingly by bond issuance. In the years after 1995, long-term interest rate fixing was intensified by calling in callable outstanding higher-yielding bonds and issuing longer-termed maturities. ${ }^{25}$ Between 1995 and 2005, the share of bills of marketable debt remained constant or even decreased to levels of around $10 \%$ to $15 \%$ of outstanding marketable debt (see Fig. 2), as increases in marketable debt were financed with a net issuance of bonds that was occasionally greater than the negative net issuance of bills. The fluctuations in the net issuance of bills are also a result of increasing redemptions of bonds issued in the 1990s, indicating that the issuance of bills was also driven by liquidity management needs (such as bridge-funding between the time of bonds coming due and the time of new bonds being issued).

Decreasing government debt since 2006 has changed the picture. In conjunction with reduced funding needs, maturing bonds issued during the 1990s have led to a negative net issuance of bonds since 2006. Between 2006 and 2010, certain factors reduced funding needs and led to a negative net issuance of either bills or bonds. First, before being transferred to the old age and survivors' insurance (OASI), the funds from the sales of the surplus gold reserves of the SNB were temporarily managed by the Confederation between 2005 and 2007. Secondly, the Confederation profited from the proceeds of the ongoing sale of Swisscom shares, particularly so in 2006 and 2007. Thirdly, in 2009, funding needs decreased due to the proceeds from selling the UBS convertible bond that was obtained by the Confederation in 2008 as part of the recapitalization of UBS. ${ }^{26}$ Since 2010 , the variability in net issuance of bills has again been related to other than structural reasons. It is mainly related to liquidity management, i.e., bridge-funding between the time of large bond redemptions in early 2012, 2013, and 2014, and bond issuing. ${ }^{27}$ As outlined above, in 2015, the shift in deliverance

\footnotetext{
${ }^{23}$ See SFS (1990 and 1991).

${ }^{24}$ Notable examples are the partial privatization of telecommunication services, the liberalization of postal services, the external financing of corresponding pension funds and the disbanding of the central treasury for these entities.

${ }^{25}$ See SFS (1995-2004).

${ }^{26}$ The CHF 6 billion capital injection in 2008 was fully covered by already available liquidity.
}

of taxes by the cantons due to negative interest rates led to high levels of liquidity followed by a general reduction of market funding by the Treasury, and considerable negative net issuance of bills. ${ }^{28}$

Figure $4 \mathrm{a}-\mathrm{f}$ shows that the issuance patterns of bonds, bills, and notes differ widely. Even within one category of debt, issued maturities and volumes may differ considerably, as may their standard deviations. ${ }^{29}$ This also holds true for the frequency of issuances. For bonds, again the grey-shaded areas in Fig. 4a mark years of long-term interest rate positioning indicated by SFS. With the exception of the period after the introduction of bills in the early 1990s, evidence from SFS suggests that the issuance of short-term debt seems to be unrelated to interest rate considerations.

Clearly, the issuance of bills shows the most regular and structured pattern in terms of frequency and maturity, i.e., fixed maturities were issued with a regular frequency (see Fig. 4c). Although the program was launched in 1979, bills only gained importance in terms of issued volumes in the early 1990s (see Fig. 4d or Fig. 2). Before this, notes were the preferred debt instrument on the short end of the yield curve. This is why predominantly 3-month bills with a low, stable average volume of around CHF 200 million were issued throughout the 1980s. Given the intention of establishing a Swiss franc money market around 1990, and fostered by the increasing debt levels in the early 1990s, the bill program was expanded by the new issuing of 6-month and 12-month bills. This was accompanied by an increased volume and a greater variability in the size of emissions. From the mid-1990s onwards, the share of bills in marketable debt, and thus the average volume of bills, slowly decreased to approximately CHF 600 to 800 million. However, the variability of volumes issued is still noticeably high, indicating that bill issuances are greatly driven by cash management concerns. Despite introducing longer maturities in the 1990s, the Treasury has kept the focus on the 3-month bill. Around $80 \%$ to $90 \%$ of the volume of outstanding bills has been issued as 3-month bills throughout the sample period. Consequently, the volumeweighted, yearly issued maturity of bills has only slightly increased since 1990.

Until 1979, short-term government debt was issued in the form of Treasury notes (Fig. 4e, f). The Treasury concentrated on issuing notes with maturities of between 3 months and 2 years. The volume-weighted, yearly issued maturity of notes reveals that the focus of the Treasury was mostly on 1-year notes. While notes show a relatively regular pattern regarding maturity and

\footnotetext{
${ }^{27}$ See SFS (2012-2014).

${ }^{28}$ See Federal Finance Administration (2016).

${ }^{29}$ From 1980 onwards, bonds were issued by tender, i.e. auction. See SFS (2003) and Ranaldo and Rossi (2016).
} 


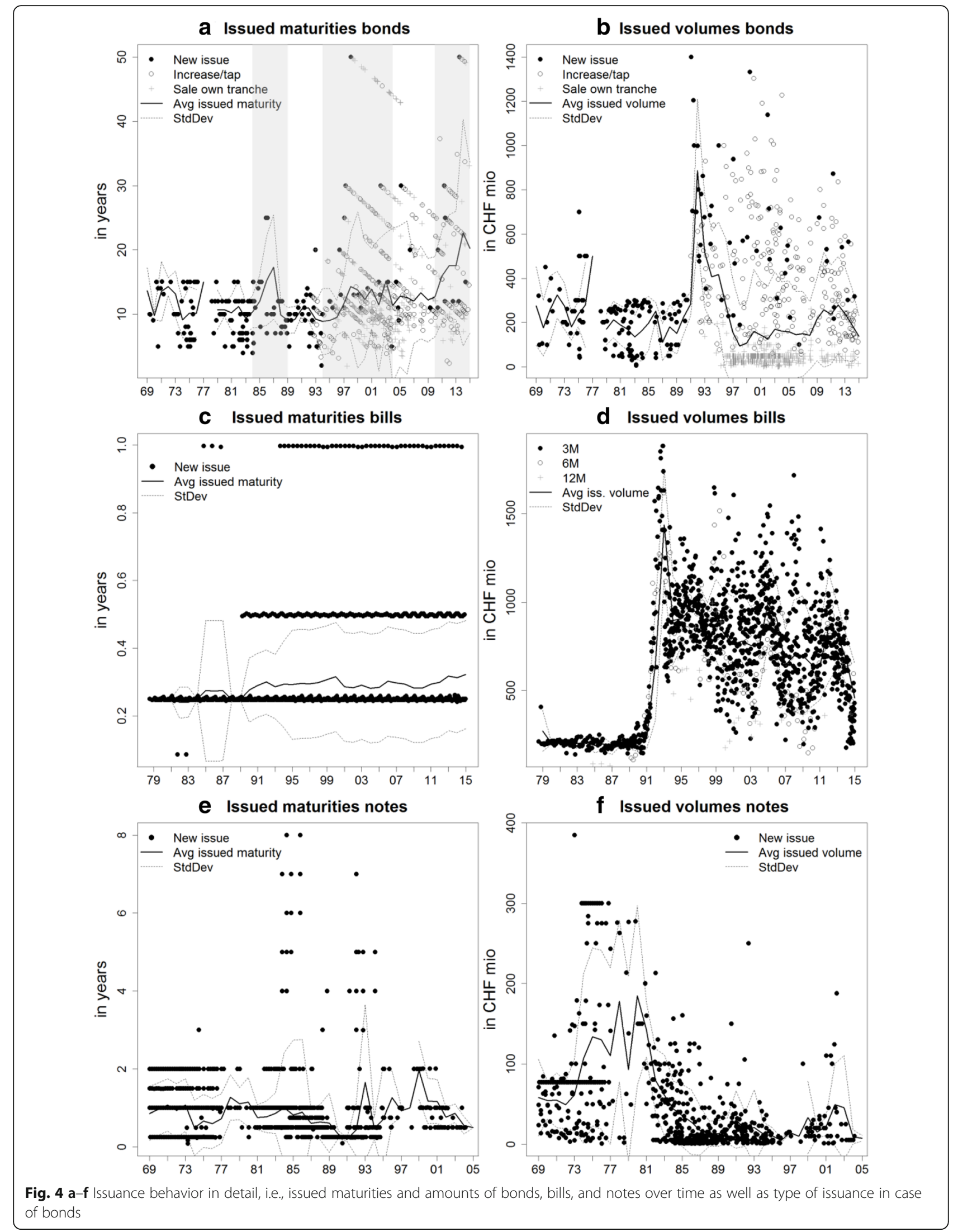


frequency throughout the 1970s, there is no predictable pattern regarding the average emission volume. The variability in volumes increases with the issuance of larger volumes from the mid-1970s onwards. With the introduction of bills in 1979, notes lost their role in short-term funding. With the decreasing importance of notes throughout the 1980s and 1990s, the issuance of notes became more dependent on funding needs and demand factors. Discontinuities and demand-driven deviations from the standard maturities and volumes are visible in Fig. 4e, $\mathrm{f}^{30}$ The Treasury started to cover a broader range of maturities and the variability of emission volumes increased. However, the Treasury kept a strong focus on three specific maturities (6-month, 12month, and 2-year notes). Although the number of emissions reached its peak in the mid-1980s, with 30-50 emissions per year, the volumes issued were rather low and the average decreased substantially. This and the increasing debt levels lowered the share of notes in total marketable debt to below 1\% in the 1990s (Fig. 2). Nevertheless, the Confederation ceased to issue notes only in 2005.

Several reasons caused the Treasury to issue notes longer than originally envisioned. First, there was the abovementioned increase in funding needs in the 1990s. Secondly, until 2005, Treasury notes were still demanded by banks, as these could be pledged at the SNB's Lombard facility (a facility similar to the Federal Reserve System's discount window). ${ }^{31}$ In 2005, the SNB switched to a new facility with the name "liquidity shortage financing facility" (LSFF). Eligible securities for LSFF credits from then on were included in the SNB repo basket that does not contain notes. From 2006 onwards, the old Lombard facility was no longer available. At the same time, the issuance of notes ceased. ${ }^{32}$

Up to the early 1990s, emissions of bonds (Fig. 4a, b) were largely driven by funding needs of the Confederation, either due to budget deficits (in the early 1970s) or redeeming debt (throughout the 1980s). Until 1991, with few exceptions (see below), only bonds with a maturity of between 5 and 15 years were issued. The Treasury focused on bonds of $5,10,12$, and 15 years. All bonds were exclusively issued as new bonds with a volume of around CHF 200 million (i.e., there were no replenishments and no sales of own tranches-see below). This pattern led to a relatively balanced maturity profile throughout these years.

From 1990 until 2005, growing funding needs went along with a higher yearly net issuance of bonds. This was accompanied by a substantial increase in the

\footnotetext{
${ }^{30}$ See e.g. SFS (1986).

${ }^{31}$ In particular, longer-termed notes were demanded by Liechtenstein banks (see e.g. SFS, 1986).

${ }^{32}$ See Nellen (2015).
}

frequency and the variability of the volume of bond emissions. Additionally, a broader range of maturities was issued. In 1991, in addition to issuing new bonds, the Confederation started to replenish outstanding bonds on a regular basis (i.e., the Treasury increased the outstanding amount of a given bond through new auctions). Replenishments are meant to increase the marketability and liquidity of bond emissions and thus serve to support the Confederation's role in constituting the Swiss franc benchmark curve. ${ }^{33}$ This change in issuance behavior can be visually identified by the "diagonal" patterns in Fig. 4a. In 1992, an emission calendar was introduced. ${ }^{34}$ From 1993 onwards, so-called own tranches ${ }^{35}$ of issued bonds were sold directly and ad-hoc to investors, depending on market demand and funding needs. Additionally, call options on own tranches were sold from 1996 to $2002 .^{36}$

The grey-shaded periods in Fig. 4a indicate periods of long-term fixing of interest rates as indicated by the Treasury in the SFS. Two such periods took place in the late $1980 \mathrm{~s}$ and late 1990s. The most recent period started in 2010 and is associated with the period of ultra-low interest rates. When engaging in interest rate fixing, the Treasury issues bonds with longer maturities and increases the volume-weighted yearly issued maturity in comparison to preceding years. ${ }^{37}$ Particularly at the beginning of these periods, the value-weighted issued maturity increased from the long-standing average and important 10 -year benchmark to around 15 years. However, until 1995, most of the bonds issued, along with the larger emissions, were still issued with a maturity of around 10 years. The Treasury started to issue longerterm bonds more regularly only after $1997 .^{38}$ After 1997 , the volume-weighted yearly issued maturity slowly approached 15 years and remained constant at this level until 2010. Thereafter, the on-going issuance of longterm maturities has ensured increases in the volumeweighted maturity of both issued debt and outstanding marketable debt (see Fig. 5).

\footnotetext{
${ }^{33}$ See SFS (1991) and Federal Finance Administration (2013; 2014).

${ }^{34}$ See SFS (1992) and Ranaldo and Rossi (2016) for more details.

${ }^{35}$ To increase its own stocks, the Treasury can itself reserve part of the bond emission. These so-called own tranches can then be sold directly to investors to support market liquidity or to benefit from favorable market conditions. See SFS (1993).

${ }^{36}$ The use of interest rate derivatives was made possible already in 1989. The Treasury adapted its debt management toolkit by selling call options on own tranches between 1996 and 2002. Unfortunately, no data on such transactions are available.

${ }^{37}$ See all SFS corresponding with the grey-shaded years. Despite the Treasury's claim to have taken advantage of the low interest rate environment (inverse yield curve) in 1988 and 1989, volume-weighted yearly issued maturity dropped back to the historical average of 10 years

${ }^{38}$ After the first 50 -year bond was issued in 1903, it took almost a century for the second 50-year bond to be issued in 1999 .
} 


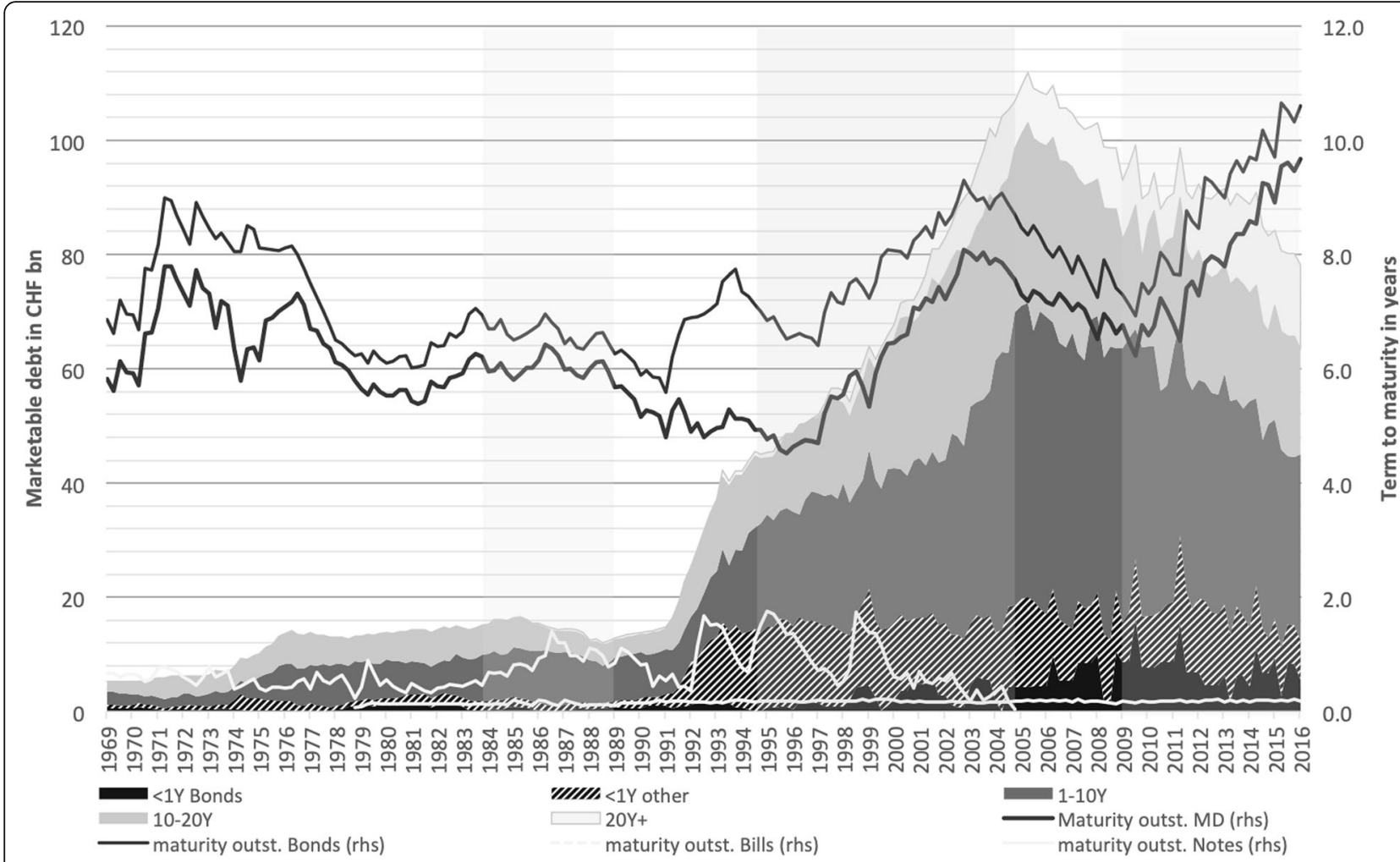

Fig. 5 Decomposition of marketable debt into selected baskets defined by the remaining maturity (bonds $<1 Y$; other debt $<1 \mathrm{Y}$ (bills and notes); 1-10Y (bonds and notes); 10-20Y (bonds); $>20 Y$ ) and volume-weighted maturity of total marketable debt ( $\mathrm{M}^{\text {out }}$ ), of bonds $\left(\mathrm{M}^{\text {out, b }}\right)$, of notes ( $\left.\mathrm{M}^{\text {out,notes }}\right)$, and of bills ( $\left.\mathrm{M}^{\text {out,bills }}\right)$

The period in the late 1980s illustrates that active, long-term interest rate positioning must not necessarily lead to corresponding changes in the value-weighted maturity of outstanding marketable debt, and it may be difficult to empirically capture the Treasury's selfdeclared, long-term interest rate positioning. Several reasons can be responsible for this. For instance, new long-term issuances might not reach a volume sufficient to move up volume-weighted outstanding debt maturity. Other factors such as an increase in the share of short-term debt (i.e., bills and notes) might also contribute to a decrease in maturity, despite long-term interest rate positioning. Technical factors such as unbalanced maturity profiles may also dampen the effects of long-term issuance. ${ }^{39}$

The change in strategy in recent years toward more long-term or ultra-long-term bonds is clearly related to the unprecedented low level of interest rates from 2010 onwards. After 2012, almost half of the issued bonds had

\footnotetext{
${ }^{39}$ Different amounts of earlier issued outstanding debt per maturity and/or irregular issuance (regarding distribution of maturity and volume) can lead to a so-called unbalanced maturity profile. If, e.g., relatively high amounts of debt issued in earlier years approach redemption while new issuance is long-term but relatively low in volume, the outstanding maturity of debt can shorten naturally.
}

a maturity of 20 years or longer. Therefore, the volumeweighted yearly issued maturity increased substantially and peaked at 22 years in 2014, when, for the third time in history, a 50-year bond was issued. It has subsequently been replenished intensively.

With regard to issued volumes, the increased frequency of bond emissions seemed to be insufficient to satisfy funding needs from 1993 to 1996. As a consequence, the average emission volume increased substantially. Figure $4 \mathrm{~b}$ shows that low size, own tranches were sold with a high frequency from 1996 to 2006. This lowered the average emission size back to its historical average range of between CHF 200 and 300 million. However, from the mid-1990s onwards, emission volumes have varied more strongly compared to before. Figure 4 reveals that the volumes of sold own tranches have been rather low compared to conventional emissions-i.e., auctions of new issues and replenishments. The last two have accounted for most of the issued bond volume.

While it is also on account of the Treasury's stronger demand orientation, the increased frequency and use of different procedures for issuing bonds, and the higher variation in emission volumes, reflect the need to obtain funds by all means between 1993 and 2005. Together 
with the decrease of total debt from 2006 onwards, the frequency of bond emissions, the relative importance of own tranche sales, the variation in emission volumes, and issued maturities have decreased. From 2010 onwards, bonds with higher volumes came due and the corresponding refunding needs-although marketable debt remained constant-led to a slightly higher emission frequency and average volumes. However, since 2010, bond issuance has followed a more regular pattern, as the variances in volume and maturity have returned to lower levels. ${ }^{40}$

\section{Maturity composition and debt management}

In this section, we analyze the maturity composition of debt and provide first qualitative and descriptive evidence on the Confederation's debt management strategy. In particular, we show that the average weighted maturity of outstanding debt is mainly influenced by the average weighted maturity of outstanding bonds and the share of short-term debt. We further relate the latter two variables to the interest rate environment and the debt-to-GDP ratio.

The Treasury's responsibility is defined so as to ensure the ability of the Confederation and affiliated institutions to fulfill their payment obligations at all times. The overall objective is to cover the Confederation's funding needs at the lowest possible costs and with an acceptable degree of risk. ${ }^{41}$ Risks include interest rate risk (the risk of (re)funding debt at higher rates of interest) and roll over risk (the risk that (re)funding might prove impossible at acceptable conditions due to the adverse market impact of large emission volumes).

While debt servicing costs may be lowered by issuing a relatively more short-term debt, this strategy involves increasing interest rate and roll over risk. Interest rate risk, i.e., fluctuations in interest payable, complicates the Confederation's budgetary management, potentially causing policy uncertainty with regard to the tax level. Furthermore, an unbalanced maturity profile may lead to a higher share of debt maturing when interest rates are high. Risk can therefore be reduced by an acceptable degree of longer-term bonds and an evenly distributed maturity profile. Similarly, roll over risk increases with a shorter maturity of outstanding debt. Also, the higher the share of debt coming due within the next year, and the more unbalanced the maturity profile of outstanding debt, the more likely will be the realization of roll over risk. Again, this may be avoided by adjusting debt maturity and maintaining an evenly distributed maturity profile. Thus,

\footnotetext{
${ }^{40}$ In 2014 and 2015, variability in issued maturity was somewhat upwardly biased because of the issuance and replenishments of the 50year Confederation bond.

${ }^{41}$ See Federal Treasury (2013).
}

tactical interest rate positioning, i.e., issuing more shortterm debt or reducing long-term bond issuance when interest rates are high, may come at the cost of higher interest fluctuations due to realized interest rate risk and higher roll over risks. In contrast, issuing longerterm maturities to reduce interest rate and roll over risk comes at the cost of having a generally higher interest rate to be paid for longer-term debt.

To manage these trade-offs, the Treasury needs to reflect a broad range of factors such as projected budget deficits or surpluses, redeeming debt, changes in internal funding sources, specific funding needs, and market demand (e.g., liquid benchmark bonds or the ability of the market to absorb new issues of specific maturities). These factors are taken into account to define the frequency and the volume of emissions. The choice of the appropriate debt instrument (e.g., interest rate type, share of short-term debt, etc.), the type of emission (e.g., syndicate or auction), and the maturity also depend on strategic or tactical considerations (e.g,. risk preferences, portfolio targets, liquidity buffers, market conditions). ${ }^{42}$

Obviously, some of these factors are either unobservable, or at least not publicly observable, making the identification of debt management strategies an intricate task. $^{43}$ In particular, market conditions (e.g., specific investor demand) and the Treasury's internal reflections and strategies ${ }^{44}$ are not directly observable (or are rarely communicated). We here focus on our new data vintage of emission data to shed some light on the maturity composition and the outstanding maturity chosen by the Treasury. ${ }^{45}$

Adjustments in debt management strategies may reflect changing interest rate risks and roll over risks. We should thus be able to relate changes in the Treasury's issuance behavior to changes in debt dynamics. As in other literature, we use the debt-to-GDP ratio to reflect debt dynamics. Instead of total debt, we consider the debt management strategy to be related to marketable debt, hence we consider the marketable debt-to-GDP ratio (MD/GDP). While non-marketable debt may influence the emission activity of the Treasury, we provide

\footnotetext{
${ }^{42}$ During the period considered, Switzerland exclusively issued Swiss franc-denominated debt.

${ }^{43}$ For instance, changes in issuance volume, i.e. funding needs, may partially reflect budget deficits or surpluses but they also depend on redeeming debt, changes in internal funding sources, or the liquidity buffer that the Treasury intends to have available. The liquidity buffer again may not only be influenced by liquidity needs, but also by strategic or political decisions.

${ }^{44} \mathrm{Such}$ as benchmark portfolios, duration targets, interest rate risk and roll-over risk considerations, liquidity buffer targets or the use of interest rate swaps to steer duration or interest rate positioning.

${ }^{45}$ Besides the value-weighted maturity of outstanding debt, maturity profiles also illustrate risk exposure and market coverage of the yield curve.
} 
evidence in the following section that non-marketable debt does not strongly influence the maturity choice. Regarding interest rate positioning, the Treasury might respond to the level of interest rates as measured by the short-term interest rate (3-month Libor, $\mathrm{y}^{3 \mathrm{~m}}$ ) and the slope of the yield curve (10-year yield minus 3-month Libor, $\mathrm{y}^{10 \mathrm{y}}-\mathrm{y}^{3 \mathrm{~m}}$ ).

The remaining maturity composition of outstanding marketable debt and the value-weighted maturity by instruments are depicted in Fig. 5 as percentages that certain baskets of maturities contribute to total debt, where the share of debt of a certain maturity basket is defined as the sum of debt in this basket divided by the sum of total marketable debt. Figure 5 puts the maturity composition into perspective with the volume-weighted maturities of total debt $\left(\mathrm{M}^{\text {out }}\right)$ and individual debt instruments $\mathrm{M}^{\text {out,b}}$ (where $\mathrm{b}$ stand for bonds), $\mathrm{M}^{\text {out,notes }}$, and $\mathrm{M}^{\text {out,bills }}{ }^{46}$ The periods when the SFS clearly points to long-term interest rate fixing are again shaded in grey.

Two major insights emerge from Fig. 5. First, the volume-weighted maturity of total outstanding marketable debt $\left(\mathrm{M}^{\text {out }}\right)$ is largely driven by the volumeweighted maturity of outstanding bonds $\left(\mathrm{M}^{\text {out,b }}\right)$. Secondly, the volume-weighted maturity of notes $\left(\mathrm{M}^{\text {out,notes }}\right)$ and bills $\left(\mathrm{M}^{\text {out,bills }}\right)$ seems not to be relevant for $\mathrm{M}^{\text {out }}$. It is thus interesting to focus on the difference between $\mathrm{M}^{\text {out,b}}$ and $\mathrm{M}^{\text {out }}$. Indeed, the difference between $\mathrm{M}^{\text {out, } \mathrm{b}}$ and $\mathrm{M}^{\text {out }}$ becomes larger, the larger the share of debt with a maturity lower than 1 year. Thus $\mathrm{M}^{\text {out }}$ is largely defined by $\mathrm{M}^{\text {out,b}}$ and the amount of debt with a maturity lower than 1 year.

For instance, during the mid-1990s, $\mathrm{M}^{\text {out }}$ temporarily decoupled from $\mathrm{M}^{\text {out,b}}$. This temporary change in relationship was related to the increasing use of bills (see Fig. 2) together with the stable average maturity of bond emissions (see Fig. 4a). With a declining share of bills and notes in the late 1990s, $\mathrm{M}^{\text {out }}$ was again largely influenced by the value-weighted maturity of bonds. Throughout recent years, the share of bills remained relatively constant at between $10 \%$ and $15 \%$ of marketable debt, and did not decisively affect the maturity of the outstanding debt portfolio. Instead, the emission of long-term bonds and ultra-long-term bonds has affected $\mathrm{M}^{\text {out,b }}$ and consequently $\mathrm{M}^{\text {out }}$.

Figure 5 also illustrates that, for instance, the decoupling in the 1990s was not due to maturing bonds (i.e., bonds with a maturity lower than 1 year). Instead, it was related to the increasing use of bills that by definition had a maturity lower than one year. We can thus define

\footnotetext{
${ }^{46}$ Value-weighted maturities are computed based on the maturities at issuance of respective issues and not on effective maturities of callable bonds. Appendix 1 shows that potential distortions from using issued maturities are rather small and, more importantly, do not affect our analysis (i.e. both maturity measures are strongly correlated).
}

a variable that may be better able to capture a debtmanagement change in relation to short-term debt. The share of short-term debt (SSTD) denotes debt issued with a maturity lower than 1 year, and consequently captures only bills and notes with a maturity lower than 1 year. These instruments can be easily and actively managed in response to policy changes. In contrast, bonds with a maturity lower than 1 year are a mere echo of past emissions and do not reflect current policy considerations.

Figure 6 clearly shows that $\mathrm{M}^{\text {out }}$ is largely defined by $\mathrm{M}^{\text {out,b }}$ and SSTD. Thus, to capture changes in the debt management strategy in response to MD/GDP and the interest rate environment, we focus on these two variables. ${ }^{47}$

Figure $7 \mathrm{a}-\mathrm{f}$ depicts the two policy variables against MD/GDP, the short-term rate $\left(\mathrm{i}^{3 \mathrm{~m}}\right)$ and the term spread $\left(\mathrm{i}^{10 \mathrm{y}}-\mathrm{i}^{3 \mathrm{~m}}\right)$. Again, grey-shaded areas indicate periods of long-term interest rate fixing as declared in SFS. Figure 7a shows no clear relation between SSTD and MD/GDP. However, sharp increases in MD/GDP seem to trigger an initial increase in SSTD followed by a decrease in SSTD (such as in the early 1990s). This indicates that increases in the debt level are initially accommodated by increases in SSTD that are later on replaced by bond emissions. Figure $7 \mathrm{~b}$ indicates that increases in $\mathrm{MD} /$ GDP correspond with funding through bonds with longer maturities. The Treasury thus seems to increase the maturity of issued bonds in response to increasing roll over risk and interest rate risk due to increasing debt levels, but generally refrains from lowering SSTD.

Figure 7c does not reveal a clear relationship between SSTD and the short-term rate. The Treasury generally seems to abstain from interest rate positioning via SSTD. Figure $7 \mathrm{~d}$ suggests a weak negative correlation between the $\mathrm{M}^{\text {out,b }}$ and the short-term rate that is present mostly during the last decade-i.e., the Treasury issues bonds with relatively longer maturities when the interest rate level is low. A similar picture is revealed by Fig. 7e, f. While SSTD seems not to respond to the term spread, there seems to be only a slightly negative relation between $\mathrm{M}^{\text {out,b }}$ and the term spread in the last 10 years. Long-term interest fixing as declared in SFS is reflected by increasing $\mathrm{M}^{\text {out,b }}$ in the latter two periods. The increase in bond issuance starting in the mid-1990s also coincides with a decrease in SSTD during this period.

\footnotetext{
${ }^{47}$ This can further be motivated mathematically. $\mathrm{M}^{\text {out }}=$ SSTD* $\mathrm{M}^{\text {out,STD }}+(1-\mathrm{SSTD}) \mathrm{M}^{\text {out,b}}$, where $\mathrm{M}^{\text {out,STD }}$ denotes outstanding maturity of short-term debt. As shown in Figure $5, \mathrm{M}^{\text {out,STD }}$ is likely to be rather constant. The maturity of outstanding bills tends to be constant, whereas the varying maturity of outstanding notes is related to notes with a maturity greater than one year. Hence $\mathrm{M}^{\text {out }}$ is almost entirely defined by SSTD and $\mathrm{M}^{\text {out,b }}$.
} 


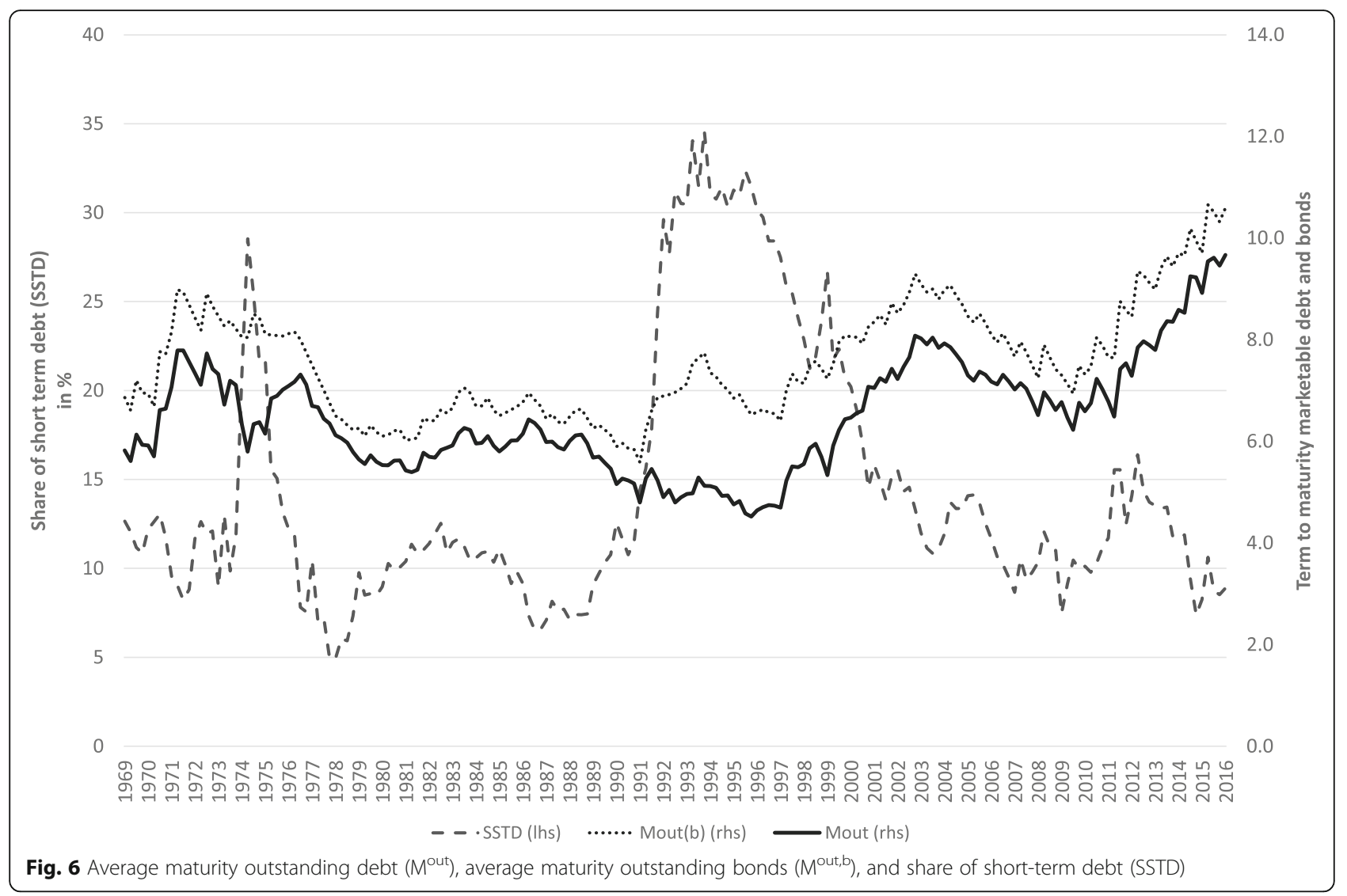

\section{Econometric analysis}

In this section, we validate descriptive and qualitative findings econometrically. We first analyze the long-run relationship between $\mathrm{MD} / \mathrm{GDP}$ and $\mathrm{M}^{\text {out,b }}$, i.e., we analyze the relationship in levels. Once we have identified the long-run effects, we focus on the short-run effect of MD/GDP on $\mathrm{M}^{\text {out,b}}$ and on SSTD, i.e., we analyze the relationship in differences. ${ }^{48}$ We further analyze whether the Treasury considers non-marketable debt (TD-MD) in determining $\mathrm{M}^{\text {out,b}}$ and SSTD, i.e., we analyze whether total debt plays a role in the Treasury's marketable debt management. Finally, we consider the interest rate environment, focusing on periods of interest rate positioning as indicated by the Treasury.

Table 2 displays descriptive statistics. The table is based on quarterly and yearly data during the observation period ranging from 1970 to 2016.

To analyze the long-run relationship between $\mathrm{M}^{\text {out,b }}$ and MD/GDP, we first consider the period from 1980 to 2008. During this period, the relationship between the two variables is relatively stable (see Fig. 7b), as it is less influenced by other effects (for instance the ultra-low

\footnotetext{
${ }^{48}$ While it would be interesting to analyze issued maturities, the Treasury did not issue any bonds in many quarters (and for 2 years). We therefore abstain from analyzing issued maturities.
}

interest rates at the end of the sample or the lack of bond emissions at the end of the 1970s). However, regressions on levels are often spurious and we find only limited significance for cointegration of the two variables $\mathrm{M}^{\text {out,b }}$ and MD/GDP (see Johannsen test results in Table 3). Consequently, we use the results from Table 3 as a mere indication of the effect of MD/GDP on $\mathrm{M}^{\text {out,b }}$ and base our conclusions mainly on the following analysis in first differences. Furthermore, as marketable debt dynamics changed in the early 1990s, we analyze the same long-term relationship for the subperiods from 1980 to 1991 and from 1992 to 2008.

The results of the following regression are reported in Table 3.

$$
M_{t}^{\text {out }, b}=\alpha+\beta_{1} M D / G D P_{t}+\varepsilon_{t}
$$

Table 3 column 1 shows that-in the long-run-the Treasury increases $\mathrm{M}^{\text {out,b }}$ by roughly 100 days in response to an MD/GDP increase of $1 \%$. This is well illustrated in Fig. 7b; the Treasury increases $\mathrm{M}^{\text {out,b }}$ by roughly 1 year if MD/GDP increases by about 4\%. In other words, the Treasury manages interest rate and roll over risk by increasing the maturity of outstanding bonds. Column 2 indicates that the long-term 


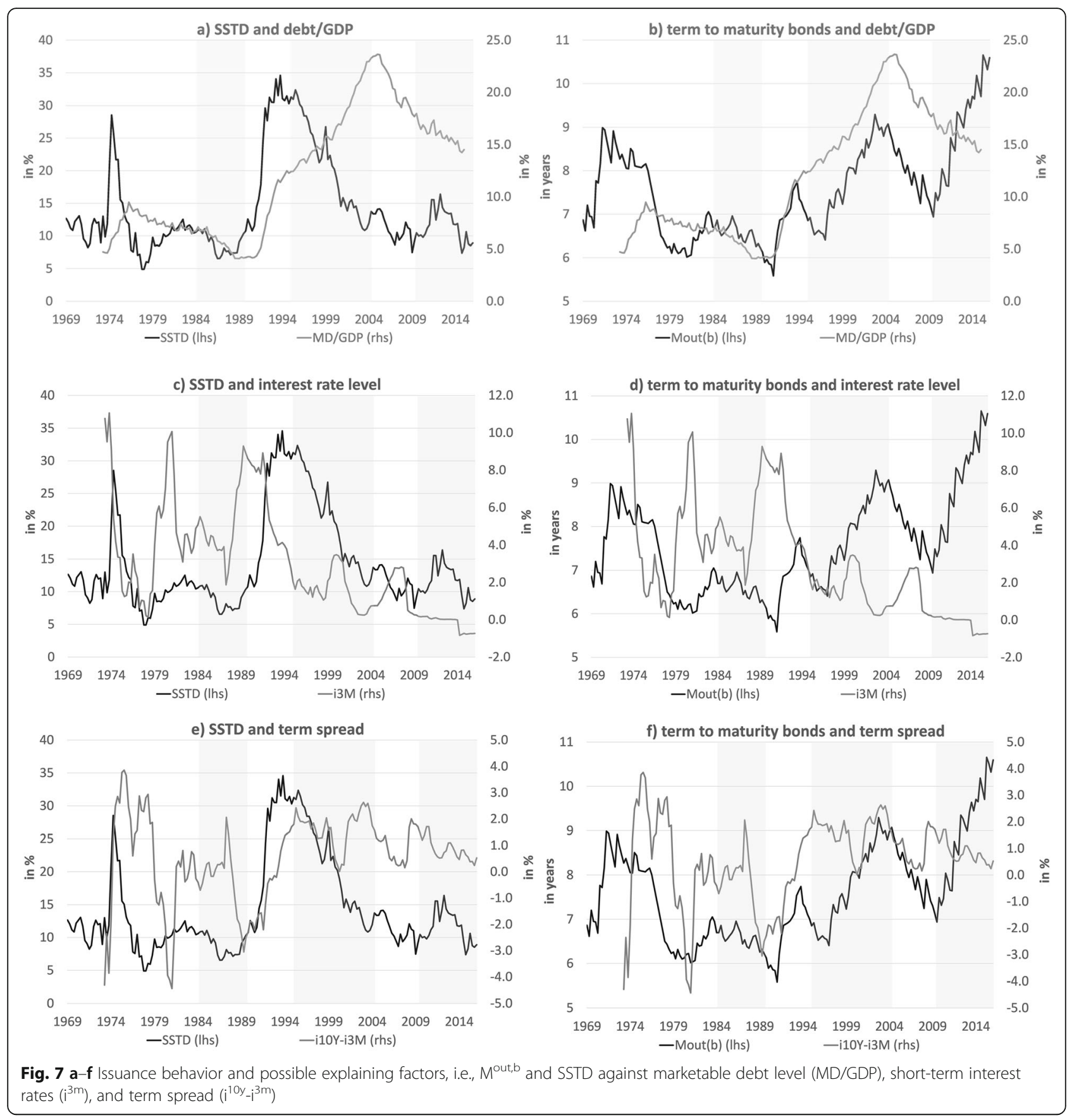

relationship is linear if tested against the variable $\mathrm{MD} /$ GDP in squared form.

While the results for the full sample ranging from 1970 to 2016 are similar but different in magnitude (see column 5 ), the error term is no longer stationary. Effects as mentioned before may overlain the long-term relationship. However, we presume that the underlying long-run effect remains valid. Later on this is confirmed when the interest rate environment is controlled for.

The results for the two periods from 1980 to 1991 and from 1992 to 2008 in columns 3 and 4 support the view that there is an effect of MD/GDP on $\mathrm{M}^{\text {out,b }}$ in the longterm. Only during 1991 to 2008, the regression is robust as a cointegration of the two variables can be identified (see Johannsen test results in Table 3). However, both periods show roughly the same coefficient for MD/GDP.

Having gained an indication for the long-run effect of $\mathrm{MD} / \mathrm{GDP}$ on $\mathrm{M}^{\text {out,b}}$, we focus on short-run effects using specifications in first differences. In a first step, we want to test whether the Treasury takes non-marketable debt into account when managing marketable debt. For this test, we use a yearly frequency, as non-marketable debt 
Table 2 Descriptive statistics

\begin{tabular}{|c|c|c|c|c|c|c|c|c|}
\hline & Unit & Mean & Median & $\operatorname{Max}$ & Min & Standard deviation & Skewness & Observations \\
\hline$\overline{M D}$ & $\mathrm{mn}$ CHF & 46108.27 & 31946.71 & 111072.75 & 5268.64 & 36934.29 & 0.41 & 188 \\
\hline TD & $\mathrm{mn}$ CHF & 69622.98 & 71613.50 & 130000.00 & 8606.00 & 42430.72 & -0.03 & 47 \\
\hline$M^{\text {out }}$ & days & 2137.93 & 2037.73 & 3749.08 & 1279.26 & 531.94 & 0.61 & 188 \\
\hline $\mathrm{MD}^{b}$ & $\mathrm{mn}$ CHF & 39231.47 & 22160.96 & 97436.65 & 4383.00 & 32587.60 & 0.53 & 188 \\
\hline$M^{\text {out }, b}$ & days & 2499.91 & 2511.81 & 3862.92 & 1458.50 & 572.96 & 0.26 & 188 \\
\hline SSTD & $\%$ & 13.06 & 10.67 & 32.40 & 2.67 & 7.62 & 1.22 & 188 \\
\hline Libor 3M & $\%$ & 3.02 & 2.24 & 11.06 & -0.79 & 2.84 & 0.89 & 172 \\
\hline Slope 10Y-3M & $\mathrm{pp}$ & 0.58 & 0.72 & 3.86 & -4.43 & 1.59 & -0.91 & 172 \\
\hline $\mathrm{MD} / \mathrm{GDP}$ & $\%$ & 10.36 & 8.43 & 21.06 & 3.75 & 5.25 & 0.41 & 188 \\
\hline (TD-MD)/GDP & $\%$ & 6.10 & 6.46 & 12.77 & 2.10 & 2.97 & 0.17 & 47 \\
\hline dummy 85-89 & binary & 0.11 & 0.00 & 1.00 & 0.00 & 0.31 & 2.55 & 188 \\
\hline dummy 95-04 & binary & 0.21 & 0.00 & 1.00 & 0.00 & 0.41 & 1.40 & 188 \\
\hline dummy 10-16 & binary & 0.15 & 0.00 & 1.00 & 0.00 & 0.36 & 1.97 & 188 \\
\hline$\triangle M D$ & $\mathrm{mn}$ CHF & 361.18 & 205.85 & 4802.25 & -7195.65 & 1699.73 & -1.02 & 187 \\
\hline$\triangle T D$ & $\mathrm{mn}$ CHF & 1985.28 & 1143.50 & 15000.00 & -11000.00 & 5174.55 & 0.26 & 46 \\
\hline$\triangle$ Mout & days & 9.66 & 2.63 & 276.49 & -234.40 & 74.59 & 0.39 & 187 \\
\hline$\triangle M D^{b}$ & $\mathrm{mn}$ CHF & 355.54 & 226.17 & 3601.02 & -4810.22 & 1317.43 & -1.00 & 187 \\
\hline$\Delta M^{\text {out }, b}$ & days & 8.38 & -6.69 & 273.98 & -92.00 & 74.93 & 0.94 & 187 \\
\hline$\triangle$ SSTD & $\mathrm{pp}$ & -0.01 & -0.12 & 9.68 & -6.66 & 1.67 & 0.90 & 187 \\
\hline$\Delta$ Libor $3 \mathrm{M}$ & $\mathrm{pp}$ & -0.07 & -0.02 & 2.49 & -3.69 & 0.78 & -0.68 & 171 \\
\hline$\triangle$ Slope 10Y-3M & $\mathrm{pp}$ & 0.03 & -0.00 & 3.22 & -2.16 & 0.67 & 1.07 & 171 \\
\hline$\triangle \mathrm{MD} / \mathrm{GDP}$ & $\mathrm{pp}$ & 0.03 & -0.01 & 1.00 & -1.23 & 0.35 & -0.19 & 187 \\
\hline$\Delta(\mathrm{TD}-\mathrm{MD}) / \mathrm{GDP}$ & $\mathrm{pp}$ & 0.02 & 0.04 & 2.77 & -2.78 & 1.04 & -0.29 & 46 \\
\hline
\end{tabular}

data is available yearly only. We consider the following two regressions for $\mathrm{M}^{\text {out,b }}$ (Eq. 2) and SSTD (Eq. 3):

$$
\begin{aligned}
\Delta M_{t}^{\text {out }, b}= & \alpha+\beta_{1} \Delta(T D-M D) / G D P_{t} \\
& +\beta_{2} \Delta M D / G D P_{t}+\beta_{3} \Delta M_{t-1}^{\text {out }, b}+\varepsilon_{t}
\end{aligned}
$$

Table 4 column 1 and 2 show an effect of roughly 100 days on $\mathrm{M}^{\text {out,b }}$ for a $1 \%$ increase in MD/GDP. As lagged MD/GDP in column 1 is not significant, the Treasury seems to increase $\mathrm{M}^{\text {out,b }}$ within 1 year. While the magnitude and the significance of the coefficients change, the economic results remain robust if assessed against the full sample (columns 5 to 8 ). ${ }^{49}$

The main result of Table 4 is that the share of nonmarketable debt ((TD-MD)/GDP) has no impact on $\mathrm{M}^{\text {out,b }}$. As non-marketable debt has no impact, we focus

\footnotetext{
${ }^{49}$ Note that by excluding MD/GDP, as done in column 4, the lagged dependent variable captures autocorrelation of MD/GDP.

Furthermore, column 6 shows a misleadingly low impact of MD/GDP on $\mathrm{M}^{\text {out,b }}$ for the full sample. This is due to other effects lowering $\mathrm{M}^{\text {out,b }}$ such as the ultra-low interest rates at the end of the observation period. As these other effects are strongly autocorrelated, column 5 reports a misleadingly low impact of MD/GDP on $\mathrm{M}^{\text {out,b }}$ in combination with a significantly autocorrelated dependent variable. See also Table 6 for further analysis of the overall observation period.
}

on the influence of marketable debt as reported in Tables 6 and 7. Before doing so, we analyze if marketable (MD/GDP) and non-marketable debt-to-GDP ((TD-MD)/GDP) influence the Treasury's cash management. Hence, we run the same regression as for $\mathrm{M}^{\text {out,b}}$ but consider SSTD as a dependent variable.

$$
\begin{aligned}
\Delta S S T D_{t}= & \alpha+\beta_{1} \Delta(T D-M D) / G D P_{t} \\
& +\beta_{2} \Delta M D / G D P_{t}+\beta_{3} \Delta S S T D_{t-1}+\varepsilon_{t}
\end{aligned}
$$

Table 5 shows that no significant effects for MD/GDP nor (TD-MD)/GDP can be identified with a yearly frequency. This is plausible, as SSTD is an indicator for the Treasury's cash management, which is used for rather short-term financing.

Overall, non-marketable debt does neither influence bond maturity nor short-term debt issuance. Consequently, in the following analysis, we focus on marketable debt. This allows us to use quarterly frequencies, which in turn increases the number of observations and thus improves the significance of the statistical tests.

Next to MD/GDP we now consider the interest rate environment. In particular, we want to analyze the Treasury's respective reaction to a favorable assessment of the 
Table 3 Long-run effects on Mout,b, quarterly frequency

\begin{tabular}{llllll}
\hline & $(1980-2008)$ & $(1980-2008)$ & $(1980-1991)$ & $(1992-2008)$ & $(1970-2016)$ \\
\hline constant & $1300.84^{* * *}(47.67)$ & $1236.85^{* * *}(114.19)$ & $1348.76^{* * *}(169.98)$ & $1343.54^{* * *}(86.76)$ & $1668.21^{* * *}(132.24)$ \\
MD/GDP & $95.83^{* * *}(4.64)$ & $109.77^{* * *}(23.84)$ & $85.52^{* * *}(30.64)$ & $93.32^{* * *}(6.47)$ & $80.32^{* * *}(10.02)$ \\
$(\mathrm{MD} / \mathrm{GDP})^{2}$ & & $-0.59(0.99)$ & & & 0.88 \\
Adjusted $R^{2}$ & 0.94 & 0.94 & 0.38 & $0.20^{* *}$ & 0.54 \\
Johansen test & $0.12^{*}$ & $0.20^{* *}$ & 0.11 & 68 & 188 \\
Observations & 116 & 116 & 48 & 0.02 \\
\hline
\end{tabular}

This table reports regressions with $\mathrm{M}^{\text {out,b }}$ as dependent variable. The dataset contains quarterly observations for each variable during the observation period ranging from 1980 to 2008 . Columns 3 and 4 split the sample into two subperiods from 1980 to 1991 and 1992 to 2008 . Column 5 shows the regression for the observation periodranging from 1970 to 2016 . $*^{* *}, *^{*}$, and * denote statistical significance (two-tailed) at the $1 \%$, 5\%, and $10 \%$ significance level, respectively. As error terms are serially correlated, we employ Newey-West standard errors. The largest eigenvalue of the Johansen test using a lag of one and its corresponding significance level are reported

interest rate environment, i.e., when the Treasury believes the interest rate environment to be attractive for longerterm debt issuance. To do so, we add three dummy variables $D_{\mathrm{n}}(n=1, \ldots, 3)$ that take the value of one for selfdeclared periods of long-term interest rate positioning $\left(D_{1}=1\right.$ from 1985 to 1989 and 0 otherwise; $D_{2}=1$ from 1995 to 2004 and 0 otherwise; $D_{3}=1$ from 2010 to 2016 and 0 otherwise). In so doing, we control for the level and the slope of the yield curve. We run the following baseline regression for $\mathrm{M}^{\text {out,b }}$ and report the results in Table 6.

$$
\begin{aligned}
\Delta M_{t}^{\text {out }, b}= & \alpha+\sum_{n=1}^{3} \beta_{n} D_{n}+\beta_{4} \Delta\left(\frac{M D}{G D P}\right)_{t-1} \\
& +\beta_{5} \Delta M_{t-1}^{\text {out }, b}+\beta_{6} \Delta M_{t-2}^{\text {out }, b}+\varepsilon_{t}
\end{aligned}
$$

Two main findings emerge from inspection of Table 6. First, the Treasury does not react to changes in MD/ GDP in the same quarter, but in the following quarter. Note, this is consistent with our earlier finding that the Treasury adjusts $\mathrm{M}^{\text {out,b }}$ within a year. Second, the Treasury reacts to the low interest rate environment from 2010 to 2016 by increasing the maturity of its bonds.

Column 2 shows that the Treasury does not react to changes in MD/GDP in the same quarter. Columns 3 and
4. split the sample into two subperiods from 1970 to 1991 and from 1992 to 2016. From 1970 to 1991, marketable debt level remained roughly constant and the Treasury relied mostly on non-marketable debt to accommodate changes in its financing needs. Therefore, no significant effect could be identified during this period. The coefficients of MD/GDP during 1992 to 2016 is roughly the same as the long-term effect reported in Table 3.

Columns 1 and 5 to 7 show that the Treasury acts according to its assessment of the interest rate environment. The Treasury does so based on a one-sided strategy, i.e., it engages in long-term interest rate positioning when considering the interest rate environment to be favorable. However, it does not engage in short-term interest rate positioning when considering the interest rate environment to be unfavorable. This one-sided strategy has been particularly pronounced in the recent ultra-low and negative interest rate environment since 2010 as indicated by the dummy $D_{3}$.

Columns 4 and 7 focus on the period from 1992 to 2016 and support the view of a one-sided strategy. First, the coefficient for the interest rate level is statistically insignificant (column 4 and 7). Second, the dummy $D_{3}$ remains statistically significant on a stand-alone basis (column 5). Third, while the slope of the yield curve is statistically significant on a stand-alone basis (column 6), it loses its

\begin{tabular}{|c|c|c|c|c|c|c|c|c|}
\hline & (1) & $(2)$ & (3) & (4) & (5) & (6) & (7) & (8) \\
\hline Constant & $0.49(23.16)$ & $-4.08(22.68)$ & $34.4(30.08)$ & $20.49(27.04)$ & $9.51(21.39)$ & $21.26(33.18)$ & $31.69(24.38)$ & $14.7(20.47)$ \\
\hline$\Delta(\mathrm{TD}-\mathrm{MD}) / \mathrm{GDP}$ & $14.52(21.88)$ & & $-0.47(24.09)$ & & $17.37(21.26)$ & & $-9.48(23.62)$ & \\
\hline$\Delta \mathrm{MD} / \mathrm{GDP}$ & $99.99^{* * *}(33.12)$ & $103.1^{* * *}(20.47)$ & & & $38.9^{*}(23.01)$ & $64.81^{* *}(25.29)$ & & \\
\hline$\Delta M^{\text {out,b }}(\mathrm{t}-1)$ & $0.03(0.29)$ & & & $0.46^{* *}(0.2)$ & $0.46^{* *}(0.15)$ & & & $0.52^{* * *}(0.14)$ \\
\hline Adjusted $R^{2}$ & 0.43 & 0.47 & -0.04 & 0.18 & 0.28 & 0.13 & -0.02 & 0.25 \\
\hline Box-Ljung (3) & 0.33 & 0.31 & 0.04 & 0.16 & 0.76 & 0 & 0 & 0.4 \\
\hline Observations & 27 & 28 & 28 & 27 & 45 & 46 & 46 & 45 \\
\hline
\end{tabular}

Table 4 Short-run effects on $M^{\text {out,b }}$, yearly frequency

This table reports regressions with $\Delta \mathrm{M}^{\text {out,b }}$ as dependent variable. The dataset contains yearly observations. Column 1 displays the baseline regression, whereas columns 2 to 8 display specific robustness checks. Column 1-4 is based on yearly observations from 1980 to 2008 and column 5 to 8 from 1970 to $2016 . *^{* * *},{ }^{*}$, and * denote statistical significance (two-tailed) at the $1 \%, 5 \%$, and $10 \%$ significance level respectively. Standard errors are reported in parentheses. For columns 1,4 , and 8, heteroscedasticity-consistent (Huber-White) standard errors are used. Column 7 displays Newey-West standard errors due to serial correlation. Due to the small number of observations, for columns 2, 3, 5, and 6 we use normal standard errors that are larger than the Huber-White or Newey-West standard errors. To test for serial correlation of the error term, we performed the Box-Ljung test with a lag of 3 (considering the small sample size) 
Table 5 Short-run effects on SSTD, yearly frequency

\begin{tabular}{lllllllll}
\hline & $(1)$ & $(2)$ & $(3)$ & $(4)$ & $(5)$ & $(6)$ & $(7)$ & $(8)$ \\
\hline Constant & $-0.21(0.58)$ & $-0.21(0.68)$ & $0.22(0.61)$ & $-0.04(0.51)$ & $-0.11(0.37)$ & $-0.09(0.5)$ & $0.04(0.46)$ & $0.01(0.44)$ \\
$\Delta($ TD-MD)/GDP & $0.44(0.47)$ & & $0.56(0.49)$ & & $0.4(0.44)$ & & $0.34(0.45)$ \\
$\Delta \mathrm{MD} / \mathrm{GDP}$ & $0.68(0.54)$ & $1.04(0.9)$ & & & $0.76(0.55)$ & $0.91(0.76)$ & \\
$\Delta \mathrm{SSTD}(\mathrm{t}-1)$ & $0.45^{* *}(0.17)$ & & $0.53^{* *}(0.19)$ & $0.2(0.18)$ & & $0.29(0.21)$ \\
Adjusted R & 0.27 & 0.88 & 0.01 & 0.26 & 0.08 & 0.06 & -0.01 & 0.06 \\
Box-Ljung (3) & 0.33 & 0 & 0.06 & 0.39 & 0.84 & 0.09 & 0.3 & 0.94 \\
Observations & 27 & 28 & 28 & 27 & 45 & 46 & 46 \\
\hline
\end{tabular}

This table reports regressions with $\triangle$ SSTD as dependent variable. The dataset contains yearly observations. Column 1 displays the baseline regression, whereas columns 2-8 display specific robustness checks. Column 1 to 4 is based on yearly observations from 1980 to 2008 and column 5 to 8 from 1970 to 2016 . ***, **, and ${ }^{*}$ denote statistical significance (two-tailed) at the $1 \%, 5 \%$, and $10 \%$ significance level respectively. Standard errors are reported in parentheses. For columns 4,5 , and 8, heteroscedasticity-consistent (Huber-White) standard errors are used. Columns 2 and 6 displays Newey-West standard errors due to serial correlation. Due to the small number of observations, for columns 1, 3, and 7 we use normal standard errors that are larger than the Huber-White or Newey-West standard errors. To test for serial correlation of the error term, we perform the Box-Ljung test and report its p-value. We use a lag of 3 (considering the small sample size)

significance, if used together with the dummy $D_{3}$ (column 7). The significance of the dummy $D_{3}$ points to a onesided strategy, whereas significant coefficients of interest rate variables would indicate a two-sided strategy. Also, $D_{3}$ displays roughly similar values in columns 1,5 , and 7.

The insignificance of the other two dummies for selfdeclared periods of interest rate positioning in column 1 may wrongly lead to the conclusion that the Treasury did not effectively engage in interest rate positioning during these two phases. As outlined in Section 4, the maturity of marketable debt is subject to substantial inertia and is further affected by technical factors. These issues make it difficult to empirically capture long-term interest rate positioning. While the first period from 1985 to 1989 is characterized by low emission volumes, the second period from 1995 to 2004 is characterized by the maturing long-term bonds that have built up with the increasing debt levels since the early 1990s. We thus refrain from making such a conclusion.

Running a similar regression with SSTD as the dependent variable for a quarterly frequency strengthens the findings above. In particular, the Treasury currently finances an increase in MD/GDP with short-term debt, and subsequently increases the volume of bonds. Current changes in MD/ GDP display a statistically and economically significant increase of around 2\% in SSTD. This may be perceived as a contraction to the yearly analysis above where such an effect does not show up. However, past changes of MD/GDP display a negative sign (while not statistically significant in columns 1 and 3). Hence, increases in SSTD in the current quarter are reduced in the next quarter. Also, this is in line with the finding above that the Treasury changes $M^{\text {out,b }}$ in the subsequent quarter in response to changes in MD/GDP.

Table 6 Short-run effects on $M^{\text {out,b }}$, quarterly frequency

\begin{tabular}{|c|c|c|c|c|c|c|c|}
\hline & $(1)$ & $(2)$ & (3) & (4) & $(5)$ & (6) & $(7)$ \\
\hline constant & $-7.06(6.38)$ & $6.96(5.3)$ & $-9.12(6.21)$ & $18.96(12.94)$ & $-3.67(7.87)$ & $42.61^{* * *}(12.75)$ & $16.87(28.91)$ \\
\hline Libor 3M & & & & $-2.88(6.57)$ & & & $0.91(7.53)$ \\
\hline Slope 10Y-3M & & & & & & $-23.41^{* * *}(7.86)$ & $-17.77(11.4)$ \\
\hline dummy 85-89 & 5.53 (10.79) & & & & & & \\
\hline dummy 95-04 & $3.34(12.9)$ & & & & & & \\
\hline dummy 10-16 & $62.62^{* * *}(15.66)$ & & & & $64.77^{* * *}(16.21)$ & & $61.71^{* *}(24.22)$ \\
\hline$\Delta M^{\text {out,b }}(\mathrm{t}-1)$ & $0.26^{* * *}(0.08)$ & $0.26^{* * *}(0.09)$ & $0.33^{* * *}(0.11)$ & $0.25^{* * *}(0.08)$ & $0.22^{* *}(0.09)$ & $0.19^{* *}(0.09)$ & $0.18^{* *}(0.08)$ \\
\hline$\Delta M^{\text {out }, b}(\mathrm{t}-2)$ & $-0.21^{* * *}(0.08)$ & $-0.06(0.09)$ & $-0.16^{*}(0.1)$ & $-0.2^{* *}(0.09)$ & $-0.26^{* *}(0.11)$ & $-0.23^{*}(0.12)$ & $-0.28^{* * *}(0.08)$ \\
\hline$\triangle \mathrm{MD} / \mathrm{GDP}$ & & $-22.82(19.33)$ & & & & & \\
\hline$\triangle \mathrm{MD} / \mathrm{GDP}(\mathrm{t}-1)$ & $98.5^{* * *}(15.13)$ & & $29.75(35.74)$ & $90.66^{* * *}(18.79)$ & $111.99^{* * *}(15.45)$ & $86.98^{* * *}(15.53)$ & $110.07^{* * *}(17.44)$ \\
\hline Adjusted $\mathrm{R}^{2}$ & 0.25 & 0.06 & 0.08 & 0.21 & 0.31 & 0.26 & 0.33 \\
\hline Box-Ljung (15) & 0.22 & 0.02 & 0.18 & 0.06 & 0.11 & 0.12 & 0.09 \\
\hline Observations & 185 & 185 & 85 & 99 & 99 & 99 & 99 \\
\hline
\end{tabular}

This table reports regressions with $\Delta$ Mout,b as dependent variable. The dataset contains quarterly observations. Columns 1 and 5 display the baseline regression for the period from 1970 to 2016 and the sub-period from 1992 to 2016 . The other columns display specific robustness checks. The dataset contains quarterlyobservations. For columns 1 and 2, the observation period ranges from 1970 to 2016, for column 3 from 1970 to 1991 and for columns 4 to 7 from 1992 to 2016 . *** **, and * denote statistical significance (two-tailed) at the 1\%,5\%, and 10\% significance level respectively. Standard errors are reported in parentheses. Forcolumns $1,2,3,5$, and 6 , heteroscedasticity-consistent (Huber-White) standard errors are used. For columns 4 and 7 Newey-West standard errors are used due to serial correlation. To test for serial correlation of the error term we performed the Box-Ljung test with a lag of 15 and we report its $p$ value 
Table 7 Short-run effects on SSTD, quarterly frequency

\begin{tabular}{|c|c|c|c|c|c|c|}
\hline & (1) & (2) & (3) & (4) & (5) & (6) \\
\hline constant & $0.14(0.16)$ & $0.07(0.17)$ & $-0.29^{* *}(0.13)$ & $-0.26(0.16)$ & $0.08(0.2)$ & $-0.64(0.53)$ \\
\hline Libor 3M & & & & $0.07(0.07)$ & & $0.16(0.13)$ \\
\hline Slope 10Y-3M & & & & & $-0.24^{*}(0.13)$ & $0(0.23)$ \\
\hline dummy 85-89 & $-0.04(0.26)$ & & & & & \\
\hline dummy 95-04 & $-0.94^{* * *}(0.3)$ & & & & & \\
\hline dummy 10-16 & $-0.01(0.29)$ & & $0.37(0.3)$ & & & $0.73^{*}(0.42)$ \\
\hline$\triangle M D / G D P$ & $2.27^{* * * *}(0.4)$ & $7.53^{* * *}(2)$ & $1.7^{* * *}(0.32)$ & $1.51^{* * *}(0.32)$ & $1.59^{* * *}(0.31)$ & $1.55^{* * * *}(0.32)$ \\
\hline$\Delta \mathrm{MD} / \mathrm{GDP}(\mathrm{t}-1)$ & $-0.54(0.42)$ & $-6.9^{* * *}(1.65)$ & $-0.35(0.32)$ & $-0.5^{*}(0.29)$ & $-0.37(0.32)$ & $-0.3(0.33)$ \\
\hline$\triangle S S T D(t-1)$ & $0.22^{*}(0.11)$ & $0.31^{* *}(0.13)$ & $0.41^{* * *}(0.11)$ & $0.41^{* * * *}(0.1)$ & $0.37^{* * *}(0.11)$ & $0.34^{* * *}(0.11)$ \\
\hline Adjusted $R^{2}$ & 0.25 & 0.38 & 0.37 & 0.36 & 0.38 & 0.38 \\
\hline Box-Ljung (15) & 0.12 & 0.34 & 0.78 & 0.52 & 0.74 & 0.62 \\
\hline Observations & 186 & 86 & 100 & 100 & 100 & 100 \\
\hline
\end{tabular}

This table reports regressions for $\triangle$ SSTD as dependent variable. The dataset contains quarterly observations. Columns 1 and 3 display the baseline regression forthe period from 1970 to 2016 and its sub-period from 1992 to 2016, whereas the other columns display specific robustness checks. The observation period rangesfrom 1970 to 2016 for column 1, from 1970 to 1991 for column 2, and from 1992 to 2016 for columns 3 to 6 . *****, and * denote statistical significance (twotailed)at the 1\%,5\%, and 10\% significance level respectively. Standard errors are reported in parentheses. Heteroscedasticity-consistent (Huber-White) standard errors are used. To test for serial correlation of the error term, we perform the Box-Ljung test with a lag of 15 and report its $p$ value

As a consequence, changes in MD/GDP are mostly absorbed by current changes in SSTD.

The Treasury seems not to consider the yield curve when determining SSTD. Despite the slope being weakly statistically significant in column 5 , economically it is rather insignificant. Furthermore, this effect disappears, if $D_{3}$ and the slope are included in column 6. The coefficients for the level remain statistically insignificant in columns 4 and 6. These findings further lend support to the claim that the Treasury follows a one-sided strategy. Furthermore, as the Treasury seems not the react on the level and the slope of the yield curve, this provides a first piece of evidence for an asymmetric strategy, i.e., the Treasury uses bonds as an instrument to adjust the maturity of marketable debt.

With the exception of $D_{1}$, dummies $D_{2}$ and $D_{3}$ are statistically and economically significant. However, the latter two dummies show divergent and changing signs. While $D_{2}$ shows a negative sign in column $1, D_{3}$ shows a statistically and economically insignificant sign in column 1 but a statistically and economically positive sign in column 6 . Under a favorable assessment of the interest rate environment, however, we would expect a negative sign, as a reduction of SSTD would allow to further expand long-term interest rate positioning. The positive sign is particularly counterintuitive in relation to the $D_{3}$ during a time when the Treasury pushed long-term interest rate fixing due to an unprecedented low interest rate level.

As the two dummies differ in sign from each other and exhibit changing significance, there is no decisive evidence for a consistent role of SSTD in relation to roll over risk and interest rate positioning. We consider these inconclusive results to lend support to the view that the Treasury follows an asymmetric and one-sided strategy.

\section{Conclusion}

This paper presents a new set of data on emissions of marketable Swiss federal government debt from 1970 onwards, together with data on total outstanding debt and its composition from the Confederation's yearly balance sheet. The data vintages are used to analyze Swiss government debt composition, to differentiate marketable and non-marketable debt, to analyze the Confederation's issuing behavior, to calculate marketable debt maturity and marketable debt-to-GDP ratios, and to analyze the Treasury's debt management.

Marketable debt is not the only form of debt the Confederation uses to finance itself. The Confederation's debt composition shows a significant share of non-marketable debt. However, non-marketable debt is not found to influence the Treasury's marketable debt management, as it neither affects the share of marketable short-term debt nor the maturity of issued bonds.

The Confederation's emission management strategy shows distinctive changes during the period considered. Until the early 1990s, the Treasury issued bonds with maturities of between 5 and 15 years on a when-needed basis. The increasing debt levels from the early 1990s onwards changed this pattern. The introduction of replenishments, sales of own tranches, and an emission calendar went in tandem with the Treasury becoming more regular and predictable. Overall, increasing debt levels resulted in a demand-driven emission management strategy.

The Confederation's debt management is in line with international practices (Jonasson \& Papaioannou, 2018). In 
particular, the Confederation increases the outstanding maturity of marketable debt in response to an increasing marketable debt level and the corresponding increase of roll-over and interest rate risk. Distinct from the U.S. (Garbade, 2007), the Confederation does not target an average maturity but seeks to actively minimize the interest rate burden when it considers the interest rate environment to be favorable. This has certainly been the case since 2005 . However, while empirically difficult to pin down, qualitative evidence suggests that the Treasury has pursued this approach since 1970. Given the unprecedented low level of interest rates, some evidence suggests that the US approach has likely changed after the GFC to a long-term interest rate fixing policy (Greenwood et al., 2014).

The approach taken by the Confederation is asymmetric in that it focuses on the maturity of bonds only, i.e., the share of short-term debt as a potential instrument to change the maturity of debt is rather mute. Furthermore, the approach is one-sided in that the Treasury tries to minimize the interest rate burden for a longer-term horizon only, i.e., it increases bond maturity when the interest rate environment is favorable, but it does not actively reduce bond maturity when the interest rate environment is unfavorable. In other words, the Treasury engages in long-term interest rate fixing.

\section{Appendix 1}

\subsection{Data sources}

Emission data:

Eidgenossen: Issuance data on Eidgenossen are available from an internal database of the Federal Treasury, containing all issuances from 1848 onwards. The dataset is not complete insofar as partial repayments and early redemptions of bonds indicated in various SFS are not fully reported, affecting the total amount of outstanding debt up to 1969. From 1970 onwards, there were no early redemptions and Eidgenossen were either not partially repaid or, if partially repaid or converted/called, then repayments or conversions were accounted for in the database. This allows us to draw a correct maturity structure of Eidgenossen from 1970 onwards.

Outstanding maturity is calculated based on ex-ante maturity at issuance and does not take into account ex-post effective maturity of callable bonds. A comparison of the two maturities reveals that potential distortions are rather small and do not affect our analysis for two reasons. First, only 59 issues (out of 1085 issues) with a value of CHF 16.7 billion (out of a total value of CHF 196 billions) were effectively called. A third of these issues were called between 1994 and 1996. The last embedded option was exercised in 2004 (i.e., there are no distortions afterwards). Secondly, even if (speculatively) assuming that bonds with an embedded call option will be called in any case (i.e. using ex-post effective maturity of called bonds), the resulting value-weighted outstanding maturity would be on average only -0.7 years lower (before 2004) and strongly correlated with the initial maturity measure based on issued maturities $(\rho=0.94)$.

Emission data collected are validated in different ways. First, the year-end outstanding amount of bonds calculated from emission data is compared and validated with the outstanding amounts reported in the yearly published state financial statements (Staatsrechnung) of the Confederation. Secondly, four publications by the Statistisches Bureau of the SNB allow us to confirm emission data from 1939 to 1979 (see SNB 1960, 1966, 1974, 1980). Later emission data from 1980 onwards is confirmed by archival material and an emission database of the SNB. SIX Information Services also provide some data on emissions from 1970 onwards.

Schatzanweisungen: The four publications by the Statistisches Bureau of the SNB include all emissions of Schatzanweisungen between 1939 and 1979. As Schatzanweisungen were issued by the SNB in the name of the Confederation, these publications are the reference data source available for emission data on Schatzanweisungen, particularly for short-term emissions. This publication ceased after 1979 when GMBF were introduced, while Schatzanweisungen were still issued until 2005. Four further data sources enabled us to harvest emission data after 1979. Despite the cessation of the publication, the Statistical Bureau continued to record data for this publication from 1980 until 1993. This material was found in the archive of the SNB and allows us to cover the years 1983 to 1993 in full. Data was validated by analyzing the State financial statements and the minutes of the Governing Board of the SNB. While there are also data available between 1980 and 1982, these data look incomplete. This may particularly be an issue towards the end of this period, because the frequency of emissions after 1982 was very regular, whereas the frequency of emissions before 1980 was somewhat irregular. Some missing data can be complemented by two additional sources: the minutes of the Board of the SNB and the sources in the Bundesarchiv (the Federal archives). However, it remains an open question as to the extent to which the dataset could be completed using these two sources. Data between 1994 and 2004 were harvested from five further sources. The SIX Information Services provide a database on emissions that reports Schatzanweisungen between 1997 and January 1999; the SNB's IT services also stored emission data of Schatzanweisungen from 1999 onwards until the last emission issued in 2005; the abovementioned data sources could also be partially validated and complemented by additional data from material archived by an employee of the SNB who worked for the Banking Operations unit during this period; we further used the Staatsrechnung (1994 to 2005) to complement our data with emissions that cross year-ends; and finally, our dataset was complemented by analyzing the minutes of the Governing Board of the SNB. We found no information on any missing emissions. 
The emission data of Schatzanweisungen can only be validated by end-of-year data from the balance sheet in the state financial statements. We can thus claim to have harvested a complete set of emissions for Schatzanweisungen with a maturity greater than one year. Furthermore, we have no missing emissions for lower maturities that cross year-ends. We believe that the dataset is near complete, but we cannot guarantee this for maturities lower than one year. This particularly holds true for the years from 1980 to 1982. Some lower maturity emissions of Schatzanweisungen might thus be missing. However, this arguably does not affect any of the variables investigated nor the regression results to any material degree.

GMBF: A complete set of GMBF emission data from 1990 onwards is stored electronically in a database of the SNB. A complete set of emission data from 1979 to 1990 is stored as paper dossiers for each emission in the archive of the SNB.

Other data:

State financial statements data (Staatsrechnung):

The yearly balance sheet published as part of the state financial statements by the Federal Finance Administration (FFA) (2013-2016) is used to validate the emission database. In addition, yearly balance sheet data are also the basis for calculating the central government debt and debt-to-GDP ratios. See below for notes issues regarding different debt definitions. Furthermore, yearly balance sheets allow us to see the structure of the debt, i.e., to differentiate between external (marketable), internal, and other non-marketable debt.

Debt and debt-to-GDP ratio:

As outlined above, the total debt-to-GDP ratio used in this paper is based on yearly balance sheet data, which may differ slightly from other total debt key figures such as total debt according to Maastricht criteria or IMF definitions. In particular, total debt according to the IMF differs substantially from the balance sheet definition of the Confederation. First, the IMF comprises all liabilities and, secondly, liabilities are valued according to their market value. As outlined in Section 2, there were changes in accounting principles and debt definitions over the years, leading to different levels of total debt and total debt-to-GDP ratios as reported in the different state financial statements (SFS). For instance, there was a strong increase in total debt between 1970 and 1980 according to SFS published between 1981 and 1990. After 1990, liabilities against the Confederation's pension fund were included in the debt aggregate. Both the SFS published after 1990 and the Schuldenbericht (2006) retroactively added these liabilities to debt figures back to 1970 , leading to higher debt levels between 1970 and 1990. Geier (2011a) uses these data from 1981 onwards, while he relies on SFS 1981 data for 1970 to 1980 . However, earlier data (19501970) are calculated by correcting SFS $1970 / 80$ to take into account the changes between SFS 1970/80 and SFS
1981. We use the series in Geier (2011a). For the total debt-to-GDP ratio, quarterly and yearly GDP data are obtained from the State Secretariat of Economic Affairs and the Swiss Federal Statistical Office. Although a GDP revision took place in autumn 2014, we have refrained from using the new series in our first steps for several reasons. First, the revised series primarily shows changes in the level of GDP but not in the trend of GDP. Secondly, the revised data only date back to 1980, which would further reduce our sample size.

\section{Abbreviations \\ (TD-MD)/GDP: Non-marketable debt to GDP ratio (\%); Libor 3M: Swiss franc 3-month Libor rate (\%); MD: Marketable debt (mn CHF); MD/GDP: Marketable debt to GDP ratio (\%); MD ${ }^{b}$ : Value of outstanding bonds (mn CHF); \\ $M^{\text {out: }}$ Value-weighted maturity of total outstanding marketable debt (days); $M^{\text {out,b: }}$ Value-weighted maturity of total outstanding bonds (days); Slope 10Y- 3M: Spread of 10 years interest rate swaps over Swiss france 3-month Libor rate (pp); SSTD: Share of short-term marketable debt to overall marketable debt (\%); TD: Total debt (mn CHF); dummy 85-89: self-declared period of long-term interest rate positioning from 1885 to 1989 (binary); dummy 95-04: self-declared period of long-term interest rate positioning from 1995 to 2004 (binary); dummy 10-16: self-declared period of long-term interest rate positioning from 2010 to 2016(binary)}

\section{Acknowledgements \\ The authors are indebted to Katrin Assenmacher, Alain Geiger, Patrick Halbeisen, Werner Hermann, Evelyn Ingold, Sébastien Kraenzlin, Signe Krogstrup, Thomas Moser, Thomas Nitschka, Enzo Rossi, Felix Schafroth, Andy Sturm, Jens Schweizer, Daniel Wittwer, Tobias Beljean, Kurt Buff, an anonymous referee, the editors of the SNB Working Paper Series, and to the participants of the $11^{\text {th }}$ PNB-SNB Joint Seminar 2014, the 2015 Annual Meet- ing of the Swiss Statistics and Economics Association and the SNB Brown Bag Seminar.}

\section{Authors' contributions}

All authors equally contributed to the manuscript. All authors read and approved the final manuscript.

\section{Authors' information}

Basil Guggenheim is Senior Economist at the Swiss National Bank, Mario Meichle is Senior Risk Controller at the PostFinance AG and formerly worked for the Federal Department of Finance, Federal Finance

Administration-Federal Treasury. Thomas Nellen is Economic Advisor at the Swiss National Bank.

\section{Funding}

All authors declare that they have not obtained any extra funding beyond their regular salary from the institutions they work or worked for.

\section{Availability of data and materials}

Data sources are explained in Appendix 1. Emission data used can be obtained from the Federal Treasury. Other data is publicly available.

\section{Competing interests}

At the time of writing the article, Mario Meichle was employed by the Federal Department of Finance, Federal Finance Administration-Federal Treasury.

\section{Author details}

'Swiss National Bank, Money Market, Börsenstrasse 15, 8022 Zürich, Switzerland. ${ }^{2}$ PostFinance AG, Risk Control, Mingerstrasse 20, 3030 Bern, Switzerland. ${ }^{3}$ Swiss National Bank, Financial Stability - Oversight, Börsenstrasse 15, 8022 Zürich, Switzerland. 
Received: 29 August 2018 Accepted: 12 August 2019

Published online: 11 September 2019

\section{References}

Aiyagari, R. S., Marcet, A., Sargent, T. J., \& Seppälä, J. (2002). Optimal taxation without state contingent debt. Journal of Political Economy, 110, 1220-1254.

Angeletos, G.-M. (2002). Fiscal Policy with Non-Contingent Debt and the Optimal Maturity Structure. Quarterly Journal of Economics, 117(2), 1105-1131.

Barro, R. J. (1979). On the determination of the public debt. Journal of Political Economy, 87, 940-971.

Beljean, T., \& Geier, A. (2013). The Swiss debt brake-has it been a success? Swiss Journal of Economics and Statistics, 149(2), 115-135.

Bhandari, A., Evans, D., Golosov, M., \& Sargent, T.J., (2017). The optimal maturity of government debt, Working Paper.

Bigio, S., Nuño, G., \& Passadore, J. (2018). A framework for debt-maturity management, Working Paper.

Bodmer, F. (2006). The Swiss debt brake: how it works and what can go wrong. Swiss Journal of Economics and Statistics (SJES), Swiss Society of Economics and Statistics (SSES), 142(III), 307-330.

Bohn, H. (1990). Tax smoothing with financial instruments. American Economic Review, 80, 1217-1230.

Bruchez, P.-A. (2003). Will the Swiss fiscal rule lead to stabilization of the public debt?, Swiss Federal Finance Administration Working Paper 4.

Buera, F., \& Nicolini, J. P. (2004). Optimal maturity of government debt without state contingent bonds. Journal of Monetary Economics, 51(3), 531-554.

Colombier, C. (2004). Eine Neubewertung der Schuldenbremse, Swiss Federal Finance Administration Working Paper 2.

Colombier, C., \& Frick, A. (2001). Ueberlegungen zur Schuldenbremse. Zurich: KOF.

Culbertson, J. (1957). The term structure of interest rates. Quarterly Journal of Economics, 71, 485-517.

Danninger, S. (2002). A new rule: The Swiss debt brake,', IMF Working Paper 02/18.

de Haan, J., \& Wolswijk, G. (2005). Government debt management in the euro area-recent theoretical developments and changes in practices, European Central Bank, Occasional Paper Series 25.

Debortoli, D., Nunes, R., \& Yared, P. (2017). Optimal time-consistent government debt maturity. Quarterly Journal of Economics, 132(1), 55-102.

Debrun, X., Epstein, N. P., \& Symansky, S. A. (2008). A new fiscal rule: should Israel go Swiss?, IMF Working Paper 08/87

European System of Accounts - ESA (2010). Luxembourg: Publications Office of the European Union, ISBN 978-92-79-31242-7.

Faraglia et al., 2018. https://www.restud.com/paper/government-debtmanagement-the-long-and-the-short-of-it/

Favero, C., Missale, A., \& Piga, G. (1999). EMU and public debt management: one money, one debt?, CEPR, Policy Paper 3.

Federal Finance Administration. Federal Treasury activity report (2013-2016). Federal Finance Administration.

Feld, L. P., \& Kirchgässner, G. (2006). On the effectiveness of debt brakes: the Swiss experience, CREMA Working Paper Series 2006-21. Center for Research in Economics, Management and the Arts (CREMA).

Garbade, K. D. (2004). The institutionalization of Treasury note and bond auctions, 1970-75, Federal Reserve Bank of New York. Economic Policy Review, 10(1), 29-45.

Garbade, K. D. (2007). The emergence of 'regular and predictable' as a treasury debt management strategy. Federal Reserve Bank of New York Economic Policy Review, 13(1), 53-71.

Garbade, K. D. (2008). Why the U.S. Treasury began auctioning treasury bills in 1920. Federal Reserve Bank of New York Economic Policy Review 14.

Garbade, K. D., \& Ingber, J. (2005). The Treasury auction process: objectives, structure, and recent adaptations. Federal Reserve Bank of New York Current Issues in Economics and Finance, 11(2), 1-11.

Garbade, K. D., \& Rutherford, M. (2007). Buybacks in Treasury cash and debt management. Federal Reserve Bank of New York Staff Report 304

Geier, A. (2011a). Die Schuldenbremse des Bundes: Hintergründe und Wirkungen PhD thesis. University of Neuchâtel.

Geier, Alain (2011b), The debt brake-the Swiss fiscal rule at the federal level, Swiss Federal Finance Administration Working Paper 15.

Geier, A., \& Bodmer, F. (2003). Application of a fiscal rule: the Swiss debt brake, mimeo. University of Basel.

Greenwood, R., \& Vayanos, D. (2014). Bond supply and excess bond returns. Review of Financial Studies, 27(3), 663-713.
Greenwood, R., Hanson, S. G., \& Stein, J. C. (2015). A comparative-advantage approach to government debt maturity. Journal of Finance, LXX(4), 1683-1722.

Greenwood, R., Hanson, S. G., Rudolph, J. S., \& Summers, L. (2014). Government debt management at the zero lower bound, Hutchins Center Working Paper 5.

Himmel, M., \& Geier, A. (2004). Erste Erfahrungen mit der Umsetzung der Schuldenbremse. Die Volkswirtschaft, 2, 5-11.

International Monetary Fund (2014), Revised guidelines for public debt management, https://www.imf.org/external/np/pp/eng/2014/040114.pdf.

Jonasson, T., \& Papaioannou, M. G. (2018). A primer on managing sovereign debtportfolio risks. IMF Working Paper No. 18/74.

Kirchgässner, G. (2013). Fiscal institutions at the Cantonal level in Switzerland. Swiss Journal of Economics and Statistics, 149(2), 139-166.

Krishnamurthy, A., \& Vissing-Jorgensen, A. (2012). The aggregate demand for treasury debt. Journal of Political Economy, 120(2), 233-267.

Krishnamurthy, A., \& Vissing-Jorgensen, A. (2015). The impact of Treasury supply on financial sector lending and stability. Journal of Financial Economics, 118 , $571-600$

Lucas, R. E. J., \& Stokey, N. L. (1983). Optimal fiscal and monetary policy in an economy without capital. Journal of Monetary Economics, 12, 55-93.

Lustig, H., Sleet, C., \& Yeltekin, S. (2008). Fiscal hedging with nominal assets. Journal of Monetary Economics, 55(4), 710-727.

Marti Locher, F. (2015). Ausgestaltung und Wirksamkeit der kantonalen Schuldenbremsen in der Schweiz: Eine ökonomische und juristische Analyse. PhD thesis, University of Bern.

Missale, A. (1999). Public debt management. Oxford: Oxford University Press.

Modigliani, F., \& Sutch, R. (1966). Innovations in interest rate policy. AER Papers and Proc, 56, 178-197.

Nellen, Thomas (2015), Collateralised liquidity, two-part tariff and settlement coordination. Swiss National Bank, Working Paper 2015-13.

Nosbusch, Y. (2008). Interest cost and the optimal maturity structure of government debt. The Economic Journal, 118, 477-498.

Ranaldo, A., \& Rossi, E. (2016). Uniform-price auctions for Swiss government bonds: origin and evolution. SNB Economic Study, 2016-2010.

Schuldenbericht. (2006). Bericht des Bundesrates über die Schuldentwicklung der öffentlichen Haushalte. Eidgenössisches Finanzdepartement.

State financial statement (1973-2014). Bern: Swiss Federal Finance Administration.

Stein, J. (2012). Monetary policy as financial-stability regulation. Quarterly Journal of Economics, 127(1), 57-95.

Swiss National Bank. (1960). Die Begebung von Schatzanweisungen des Bundes 1939 bis 1959. Statistisches Bureau der SNB.

Swiss National Bank. (1966). Die Begebung von Schatzanweisungen des Bundes von 1960 bis 1965. Statistisches Bureau der SNB.

Swiss National Bank. (1974). Die Begebung von Schatzanweisungen des Bundes von 1966 bis 1973. Statistisches Bureau der SNB.

Swiss National Bank. (1980). Die Begebung von Schatzanweisungen des Bundes von 1974 bis 1979. Statistisches Bureau der SNB.

\section{Publisher's Note}

Springer Nature remains neutral with regard to jurisdictional claims in published maps and institutional affiliations.

\section{Submit your manuscript to a SpringerOpen ${ }^{\circ}$ journal and benefit from:}

- Convenient online submission

- Rigorous peer review

- Open access: articles freely available online

High visibility within the field

- Retaining the copyright to your article

Submit your next manuscript at $>$ springeropen.com 